\title{
De danske civilfanger under Første Verdenskrig
}

\author{
Af Mogens RostgaArd Nissen
}

Ved udbruddet af Første Verdenskrig blev knap 300 dansksindede slesvigere interneret, og de dansksindede aviser i Nordslesvig og Flensborg blev forbudt. De fleste var arresteret frem til midten af september 1914, hvorefter de igen blev frigivet. Begrundelsen for arrestationerne var, at de militære myndigheder frygtede, at de dansksindede slesvigere ville spionere mod Tyskland. Derfor var der i fredstid opstillet navnelister over dem, der skulle arresteres ved krigsudbruddet. Få dage inden krigen brød ud, kom der kontraordre fra Krigsministeriet og Indenrigsministeriet i Berlin. Regeringen ønskede alligevel ikke at foretage præventive interneringer og avislukninger i Nordslesvig, men disse nye instrukser blev ikke fulgt af de lokale myndigheder i Slesvig-Holsten.

\section{Indledning}

Ved Første Verdenskrigs udbrud i begyndelsen af august 1914 blev flere hundrede dansksindede slesvigere anholdt og sat i arrest. De fleste af disse såkaldte civilfanger sad i fangenskab i flere uger. Samtidig blev de dansksindede aviser i Nordslesvig lukket, og først i slutningen af august fik aviserne igen lov til at udkomme. De frigivne fanger blev tvunget til at underskrive erklæringer om, at de ikke ville deltage i danske foreninger eller danske møder, og at de ikke ville udvise »tyskfjendtlig adfærd «. Aviserne blev pålagt streng censur, og de fik kun lov til at udkomme, hvis de undlod at skrive "agitatoriske artikler«.

Arrestationerne $^{1}$ og forbuddet mod de danske aviser blev af de dansksindede slesvigere opfattet som en stor uret, begået af de tyske myndigheder. Og det var et overgreb, der blev husket lang tid efter krigens afslutning i 1918 og Nordslesvigs genforening med Danmark to år senere. Gennem årene er der udkommet talrige erindringer skrevet af dem, der blev holdt i fangenskab, ligesom »Foreningen Danske Civilfanger 1914 « blev stiftet som en slags selskabelig forening, hvor de gamle civilfanger fra Sønderborg Amt helt frem til midten af 
1960 'erne mødtes regelmæssigt. Interneringerne er fortsat et emne, mange sønderjyder har kendskab til, fordi så mange familier blev berørt heraf. Det er således stadig noget, der ligger dybt i sønderjydernes kollektive erindring om Første Verdenskrig og om den periode, hvor Sønderjylland var en del af Tyskland.

Baggrunden for arrestationerne og for forbuddet mod de danske aviser blotlægger nogle vigtige konfliktflader mellem forskellige tyske myndigheder, der grundlæggende var gældende gennem første halvdel af det 20. århundrede. For det første bestod der en interessekonflikt mellem de civile og de militære myndigheder. I dette tilfælde mellem Udenrigsministeriet og Indenrigsministeriet på den ene side, og Krigsministeriet og generalkommandoen i Altona på den anden. For det andet var der i forhold til det danske mindretal i Slesvig store interesseforskelle mellem de centrale civile myndigheder i Berlin - og her igen Udenrigsministeriet og Indenrigsministeriet - og de lokale myndigheder i Slesvig, især overpræsidenten i Slesvig og de lokale landråder i Tønder, Aabenraa, Haderslev, Flensborg og Sønderborg samt overborgmesteren i Flensborg. Disse interessekonflikter var afgørende for, at arrestationerne og avisforbuddene blev gennemført, og for at der gik forholdsvis lang tid, inden fangerne blev frigivet og avisforbuddet ophævet. De var også meget afgørende for, at omfanget af arrestationer varierede betydeligt mellem de forskellige nordslesvigske kredse, og for at forholdene for fangerne tilsvarende var meget forskellige.

I denne artikel er fokus rettet mod baggrunden for interneringen af de dansksindede og for lukningen af de danske aviser i Nordslesvig i perioden fra den 31. juli 1914 til begyndelsen af december samme år, hvor den sidste danske fange blev frigivet. De to ting hang tæt sammen, idet dansksindede journalister og redaktører var blandt de første, der blev arresteret. I forlængelse heraf er spørgsmålet, hvad der blev gjort for at få frigivet fangerne og genåbnet aviserne, og hvorfor der gik så lang tid, inden det skete.

Arrestationerne er som nævnt et emne, der fylder meget i den sønderjyske erindring om Første Verdenskrig, men det er ikke et emne, der fylder ret meget i den sønderjyske historieskrivning. Den tyske historiker Karl Alnor udgav i 1927 Die Schleswigsche Frage und der Weltkrieg, hvor han også kom ind på myndighedernes overgreb mod de dansksindede i august 1914 . $^{2}$ Alnor er en problematisk historiker, idet hans fremlægning er meget tendentiøs til fordel for regeringen 
og de centrale myndigheder i Berlin og til ugunst for de militære og de lokale slesvigske myndigheder. Samtidig er han udpræget tysk i sine vurderinger, og han har ikke meget til overs for de dansksindedes kritik af arrestationerne og avislukningerne, ligesom han er meget kritisk over for den ledende dansksindede redaktør og politiker, H.P. Hanssen. ${ }^{3}$ Alligevel har han fat i nogle vigtige pointer i relation til forholdet mellem de civile og militære og mellem de centrale og lokale tyske myndigheder, ligesom han i fremstillingen inddrager lange afskrifter fra nogle helt centrale kilder.

På dansk side er der kun få historikere, der har arbejdet seriøst med emnet. Tættest på kommer René Rasmussen, der i antologien Sønderjyderne og den store krig 1914-1918 har skrevet den korte oversigtsagtige artikel »Interneringen af de danske ledere og farvandskyndige i 1914 «. ${ }^{4}$ Rasmussen fokuserer især på fangernes forhold i de fem forskellige byer i Slesvig, mens han ikke går i dybden med baggrunden for arrestationerne.

Til gengæld er der udgivet en lang række erindringsbøger og artikler. I denne artikel bliver disse erindringer brugt som primære kilder, men der er det store problem ved flere af erindringerne, at de er skrevet og udgivet, længe efter begivenhederne fandt sted. Og mange af erindringerne bærer præg af, at de blev skrevet med udgivelse for øje. Der er også flere af erindringerne, der henviser til eller gengiver længere passager af andres erindringer. Derfor er det vanskelige, men dog meget brugbare kilder fra en lang række mennesker, der selv blev holdt fangen gennem kortere eller længere tid. Blandt erindringslitteraturen er det især H.P. Hanssens Fra Krigstiden og O.D. Schacks Grænsesind. Optegnelser fra årene 1913-49, der benyttes. ${ }^{5}$ Hanssen udgav sine udførlige dagbogsnoter i 1924, men en del steder er de tydeligvis blevet redigeret inden udgivelsen. ${ }^{6}$ Alligevel er denne dagbogsudgivelse helt central, fordi han skriver udførligt om sine forsøg på at få frigivet fangerne og genåbnet aviserne via en løbende kontakt til sine mange vigtige politiske kontakter i Berlin. Schacks erindringer er nedskrevet i 1916, og de er baseret på hans samtidige dagbøger og korrespondance. Schack er en central skikkelse, fordi han var den af de arresterede, der med næsten fire måneder sad længst tid i fangenskab. Samtidig forsøgte de tyske myndigheder at få ham dømt for landsforræderi, men måtte til sidst lade sagen falde, fordi de ikke kunne finde beviser mod ham. 


\section{Baggrunden for arrestationerne}

Lang tid inden krigen blev erklæret, havde de tyske militære myndigheder forberedt sig på at gennemføre foranstaltninger i forbindelse med krigsudbruddet mod forskellige grupperinger i Tyskland. Det var foranstaltninger, der var rettet mod de forskellige mindretal og mod den politiske opposition, hvilket især vil sige Socialdemokratiet. ${ }^{7}$ Formålet var at arrestere mennesker, der blev regnet som upålidelige - «unzuverlässig « - og målet var præventivt at internere disse mennesker, inden de kunne nå at sende krigsvigtige oplysninger til udlandet. Der var overordnet tale om to forskellige grupper af internerede: 1) En gruppe farvandskyndige fiskere, sømænd eller andre, som man frygtede ville kunne give fjenden nyttige oplysninger om farvandet langs Slesvigs kyster og 2) en gruppe politiske fanger, der formodedes at ville udnytte krigen til at forsøge at få gennemført en politisk ændring i Tyskland ved at støtte eller spionere for fjenden.

Den preussiske krigsminister, Hermann von Stein, forklarede 17. marts 1917 Rigsdagens finansudvalg om baggrunden for udfærdigelsen af listerne med navne på dem, der skulle arresteres. ${ }^{8}$ Han forklarede, at det var de civile myndigheder, der i fredstid havde opstillet listerne, fordi det var disse myndigheder, der havde det nødvendige lokalkendskab. »De kunne derfor bedst udpege, hvem der var farlig og derfor burde sættes i varetægtsarrest. [...] For militæret gjaldt det kun om at sikre sig mod spionage. « ${ }^{9}$ Hans udtalelser skal især ses i relation til, at der i Elsass-Lothringen blev arresteret rigtig mange mennesker, og på mødet oplyste en oberst von Wriesberg, at der fortsat pr. 1. december 1916 var 573 fra dette område, der sad i fangenskab. Det mødte stærk kritik i finansudvalget, og krigsministeren kan derfor have haft god grund til at kaste skylden for udformningen af interneringslisterne på de civile myndigheder. Men uanset at flere udvalgsmedlemmer forsøgte, fik de aldrig noget fyldestgørende svar på kriterierne for, hvem der blev skrevet på interneringslisterne.

Karl Alnor har beskrevet, at det var de lokale landråder, ${ }^{10}$ der i samarbejde med politiforvaltningen i de enkelte byer samt amtsforstanderen $^{11} \mathrm{i}$ de fire amter, der udfærdigede listerne med navnene over dem, der skulle interneres ved krigsudbruddet. ${ }^{12}$ Han understreger til gengæld, at de lokale sognerådsformænd ${ }^{13}$ blev holdt udenfor, hvilket formentlig hænger sammen med, at mange af disse i Nord- 
slesvig var dansksindede. Overpræsidenten i Slesvig, von Bülow, fungerede som forbindelsesled mellem generalkommandoen i Altona og landråderne i Nordslesvig, men modtog ellers sine instruktioner fra Indenrigsministeriet. At det var de ledende embedsmænd og politifolk i amterne, der var bestemmende for, hvem der kom på listen med »upålidelige«, kan forklare de store lokale forskelle, der var i Nordslesvig, jf. nedenfor.

Denne udlægning passer nøje med det indtryk, man får, når man går gennem materialet $\mathrm{i}$ overpræsidentens arkiv i Landesarchiv Schleswig-Holstein. ${ }^{14}$ Allerede den 4. maj 1906 skrev chefen for admiralstaben et brev til overpræsidenten, hvor han instruerede denne om at sikre, at der blev udfærdiget lister med navnene på skibsfartskyndige personer, der i tilfælde af krig ville kunne benyttes som lodser af fjenden. Formålet med listerne var, at disse personer skulle fjernes fra de respektive steder ved krigsudbruddet. ${ }^{15}$ I de følgende år blev listerne revideret hvert år, men først i løbet af 1913 blev der for alvor gjort noget ved sagen.

Efter krigens udbrud var der løbende kontakt mellem de lokale sønderjyske landråder og generalkommandoen i Altona, hvor landråderne indstillede, hvem der skulle arresteres, mens generalkommandoen på dette grundlag udstedte ordrerne. ${ }^{16}$ Der var således en tæt og effektiv kontakt mellem landråderne og generalkommandoen, mens overpræsidenten i højere grad var rådgivende for landråderne, og han blev ofte blot informeret om, hvad der var sket i de enkelte amter, når det var sket.

Denne forklaring passer fint med de begrundelser for arrestationerne, der er angivet i nogle samtidige navnelister over interneringerne. ${ }^{17}$ Listerne bærer præg af at være officielle, og de er formentlig udfærdiget i midten af september 1914, men det er uvist, hvordan H.P. Hanssen har fået fingre i listerne. Under listen med "politiske fanger» fra Aabenraa er det noteret: »Arresteret af landråden efter krigsudbruddet efter telefonisk instruktion af generalkommandoen «. Nedenunder, på den samme liste, står der under dem, der blev interneret i Gråsten, den samme indledning, men sætningen afsluttes med »arresteret af amtsforstanderen i Gråsten «. Noget tilsvarende står der under dem, der er arresteret $\mathrm{i}$ andre mindre byer som Barsmark, Rinkenæs og lignende. På listen over internerede fiskere og søfolk fra Før 
og Rømø er det noteret, at generalkommendoen i fredstid havde befalet, at landråden og amtsforstanderen ved krigsudbruddet skulle forlange, at disse skulle forlade øerne.

De oprindelige arrestationslister var formentlig mere omfattende end det antal mennesker, der blev interneret i løbet af august 1914. Det hænger sammen med, at den tyske krigsminister von Falkenhayn den 25. juli 1914 udsendte nye retningslinjer til alle generalkommandoer. Her skrev han utvetydigt $\mathrm{i}$ indledningen: »Regeringen ønsker ikke, at der foretages stærke præventive foranstaltninger mod politiske partier gennem undertrykkelse af deres presse og anholdelser af deres ledere. I stedet skal der gennemføres en passende streng overvågning af den socialdemokratiske, polske, danske og elsass-lothringske presse og partier. ${ }^{18}{ }^{8}$ Han fortsatte med at understrege, at avisforbud og arrestationer kun måtte finde sted, hvis disse "politiske partier « overtrådte den tyske straffelov, mens præventive interneringer kun måtte ske i særligt begrundede tilfælde. Disse retningslinjer blev sendt videre den 31. juli 1914 af den kommanderende general af 9. armekorps i Altona, von Roehl, til alle de militære myndigheder, der var underlagt ham, heriblandt de militære myndigheder i SlesvigHolsten. ${ }^{19}$

To dage efter krigsministerens nye retningslinjer sendte indenrigsminister von Loebell lignende instruktioner til overpræsidenten i Slesvig, von Bülow, der øjensynligt fattede budskabet. I hvert fald gjorde han dagen efter - den 28. juli 1914 - over for regeringsråd Ukert i Slesvig klart, at »naturligvis skal der udøves den yderste tilbageholdenhed med arrestationerne, og der skal kun gennemføres arrestationer, når der er klare grunde til at gøre det. Alt for omfattende og ikke ordentlig begrundede arrestationer vil uden tvivl ikke blive forstået, heller ikke i de venligstemte kredse. Og i de kredse, hvor den fædrelandskærlige indstilling generelt ligger fjernt, ville den ønskværdige mulighed for en opflammende begejstring ved krigsudbruddet blive stærkt beskåret, om ikke helt berøvet «. ${ }^{20}$ Von Bülow havde således klart givet udtryk for, at omfattende arrestationer i Slesvig kunne tænkes at få meget negative følgevirkninger i området. Det var ikke blot den danske del af befolkningen, som ville opfatte det som uretfærdige overgreb. Man kunne også forvente, at den tysksindede del af befolkningen ville have svært ved at forstå det rimelige i arrestationerne, ligesom den nationalt indifferente del af befolkningen - de »blakkede« - ville blive frataget muligheden for en tyskna- 


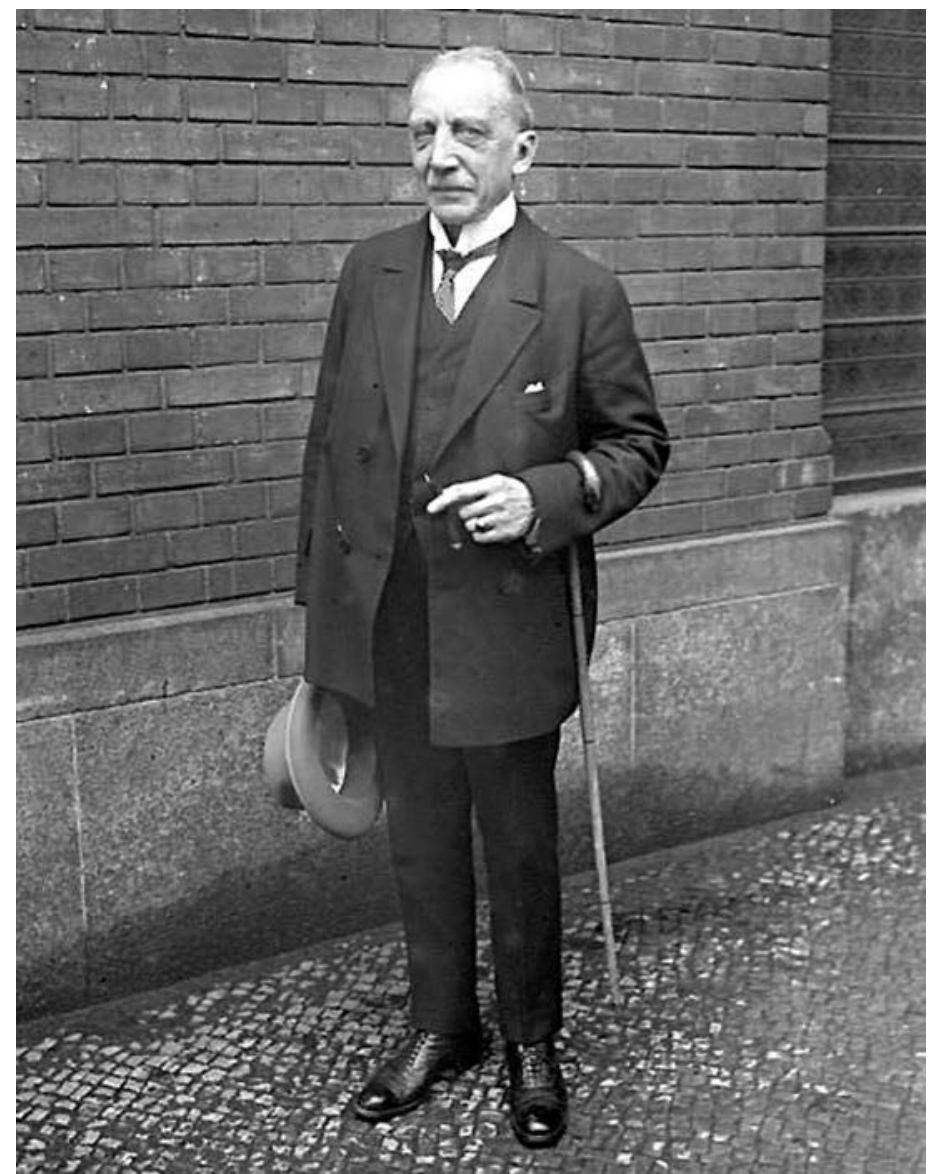

Indenrigsminister von Loebell og regeringen ønskede ikke, at der blev foretaget præventive arrestationer $i$ Nordslesvig. Alligevel valgte de lokale landråder i samspil med generalkommandoen i Altona og overpræsidenten i Slesvig at gennemføre interneringerne. Fotograf: Georg Pahl. Bundesarchiv: Bild Nr. 102-12673.

tional opblomstring i forbindelse med krigsudbruddet. Han mente altså kort sagt, at omfattende arrestationer kunne tænkes at få nogle meget uheldige virkninger i Nordslesvig.

Det er dog også vigtigt at bemærke, at både den kommanderende general og overpræsidenten anerkendte, at det kunne være nødvendigt at foretage nogle præventive arrestationer, men at der skulle være nogle meget gode begrundelser for at gøre det. Dette må opfat- 
tes som den kattelem, der gjorde det muligt for flere af landråderne og amtsforstanderne at foretage ganske omfattende præventive arrestationer. At de dansksindede aviser samtidig blev forbudt, stred klart imod krigsministerens og general von Roehls instruktioner til de forskellige militære myndigheder i Slesvig-Holsten.

Der er ikke med sikkerhed fundet nogle lister opstillet før krigsudbruddet, men i overpræsidentens arkiv er der en udateret liste fra Haderslev Amt. På denne liste er der opført 201 navne, hvoraf langt de fleste kom fra omegnskommunerne, mens der kun var noteret en halv snes stykker fra selve Haderslev. ${ }^{21}$ Det forekommer overvejende sandsynligt, at dette var en liste udfærdiget i månederne inden krigens udbrud, og hvis det er tilfældet, havde de lokale myndigheder altså forberedt sig på at arrestere omkring seks gange så mange mennesker, som man endte med at arrestere i de første dage efter krigsudbruddet.

\section{Interneringen af dansksindede slesvigere}

Fra den 31. juli 1914 gik myndighederne i gang med at internere dansksindede slesvigere, og som det fremgår af nedenstående figur, var det især i Sønderborg Amt, at det greb om sig. Opgørelsen er foretaget af Karl Alnor, og han har ikke angivet sine kilder, men tallene svarer nøje til nogle samtidige lister, der tilsyneladende er udarbejdet enten af de militære eller de civile tyske myndigheder i midten af september 1914, kort efter at de fleste fanger var blevet frigivet. ${ }^{22}$ Dog har der indsneget sig en afgørende fejl hos Alnor i forhold til Aabenraa, hvor Alnor har angivet, at der blev interneret 42 farvandskyndige og syv politiske fanger. ${ }^{23}$ Det forholder sig lige omvendt, idet det af den samtidige navneliste fremgår, at der blev arresteret otte fiskere fra Barsø, mens der er nævnt 40 internerede politiske fanger. ${ }^{24}$ Når man læser brødteksten hos Alnor, fremgår det da også, at langt de fleste arresterede i Aabenraa Amt var politiske fanger. ${ }^{25}$ Selv om det totale antal arresterede således svarer ret præcist med Alnors opgørelser, er det en vigtig nuancering, at hovedparten af de internerede altså blev arresteret af rent politiske grunde. Langt de fleste af de internerede kom fra Aabenraas opland, mens der kun er nævnt seks arresterede fra Aabenraa by, heriblandt den dansksindede redaktør og rigsdagsmand H.P. Hanssen. 
Antallet af arresterede dansksindede slesvigere i perioden augustnovember 1914

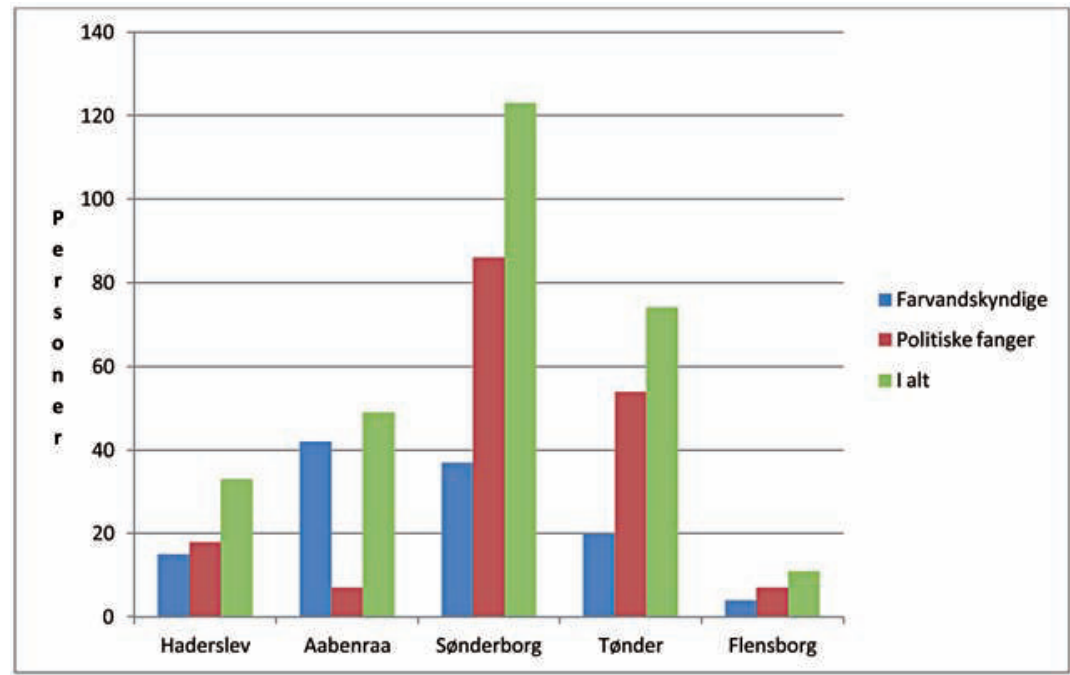

Kilde: Alnor 1927, s. 698.

Alnor har beregnet, at der i alt var 290, der blev interneret i løbet af august 1914. Af dem var 118 farvandskyndige og 172 politiske fanger, men tages der højde for den opgjorte fejl i Aabenraa, må det rettelig være 83 - svarende til knap $30 \%$ - arresterede farvandskyndige og 207 - godt $70 \%$ - politiske fanger. ${ }^{26}$ Dette niveau passer som nævnt ret præcist med nogle samtidige navnelister, der ligger i H.P. Hanssens arkiv på Landsarkivet i Aabenraa. ${ }^{27}$ I forhold til arrestationerne i Sønderborg Amt svarer Alnors tal også nøje til en opgørelse, som er foretaget af N. Kristensen Nielsen den 26. oktober 1934, og som han sendte til foreningen »Danske Civilfanger 1914«. Nielsen har noteret, at hans opgørelse er nedskrevet på basis af en interneringsliste fra 1914 foretaget af de internerede selv. ${ }^{28}$ Derfor forekommer Alnors opgørelse over antallet af internerede i de fem forskellige amter at være retvisende og formentlig også ganske præcis.

Senere i bogen har Karl Alnor plottet arrestationerne ind på et kort over Nordslesvig og Flensborg. ${ }^{29}$ Kortet giver et klart visuelt indtryk af, hvor der blev foretaget flest arrestationer. Det er interessant, at det var i Haderslev Amt - som lå helt op til den danske grænse - at der var klart færrest internerede, hvis vi ser bort fra Flensborg. Logisk set 
ville man forvente, at der i dette grænseamt ville have været det største behov for at foretage præventive arrestationer. Både fordi stort set hele befolkningen var dansksindet, og fordi det var forholdsvis let illegalt at gå over grænsen til Danmark. Når militærledelsens begrundelse for at foretage præventive arrestationer netop var at forhindre spionage, forekommer det således ulogisk, at der i byer tæt på grænsen som Københoved og Rødding kun blev arresteret fire dansksindede, mens der i byer som f.eks. Gråsten og Rinkenæs - der lå næsten $60 \mathrm{~km}$ fra grænsen - samlet blev arresteret 24. Det passer i hvert fald ikke ret godt med spionage-argumentet. Omvendt skal det naturligvis tages i betragtning, at der i området ved Flensborg og Sønderborg var flådebaser og andre militære installationer, der øgede risikoen for spionage betragteligt. Således blev den dansksindede journalist, Andreas Grau, sammen med sin hustru arresteret igen i slutningen af oktober, fordi han havde cyklet rundt på Als og angiveligt indsamlet informationer fra mange mennesker, som blev bragt til Danmark af hustruen. Sagen faldt dog, men den illustrerer, at myndighederne i dette område var meget opmærksomme på, om der foregik noget mistænkeligt. ${ }^{30}$

Flere har tillagt de enkelte landråder i amterne meget stor betydning for, hvem og hvor mange der blev arresteret. I Sønderborg Amt har også de lokale amtsforstandere haft en afgørende indflydelse på arrestationerne. I dette amt overtog den tysknationale jurist, Curth Schönberg, embedet som landråd i august 1912, og han kom hurtigt til at stå i spidsen for den nationale tyske bevægelse i Nordslesvig. Han var kendt for at føre en hårdhændet politik over for den dansksindede befolkning, og i 1919 var den overvejende dansksindede Sonderburger Kreistag parat til at gennemføre forundersøgelser af hans arbejde som landråd, da man mente, der var begrundet mistanke om embedsmisbrug. ${ }^{31}$ Inden sagen kom i gang, nåede Schönberg dog at flytte videre til Lauenburg, hvor han startede som landråd i begyndelsen af 1920. Schönberg var altså kendt som en hård tysknational embedsmand, og det er utvivlsomt en hovedforklaring på, at der blev foretaget så mange præventive arrestationer i Sønderborg Amt.

Under sig havde Schönberg de to amtsforstandere Peter Kier på Sydals og Peter Klinker på Nordals. Kier var berygtet for at føre en hård linje over for de dansksindede i de sogne, der hørte ind under ham. Alnor har kort og godt noteret: »Forholdene var værst [med hensyn til arrestationer af dansksindede] i de sogne, der lå under 


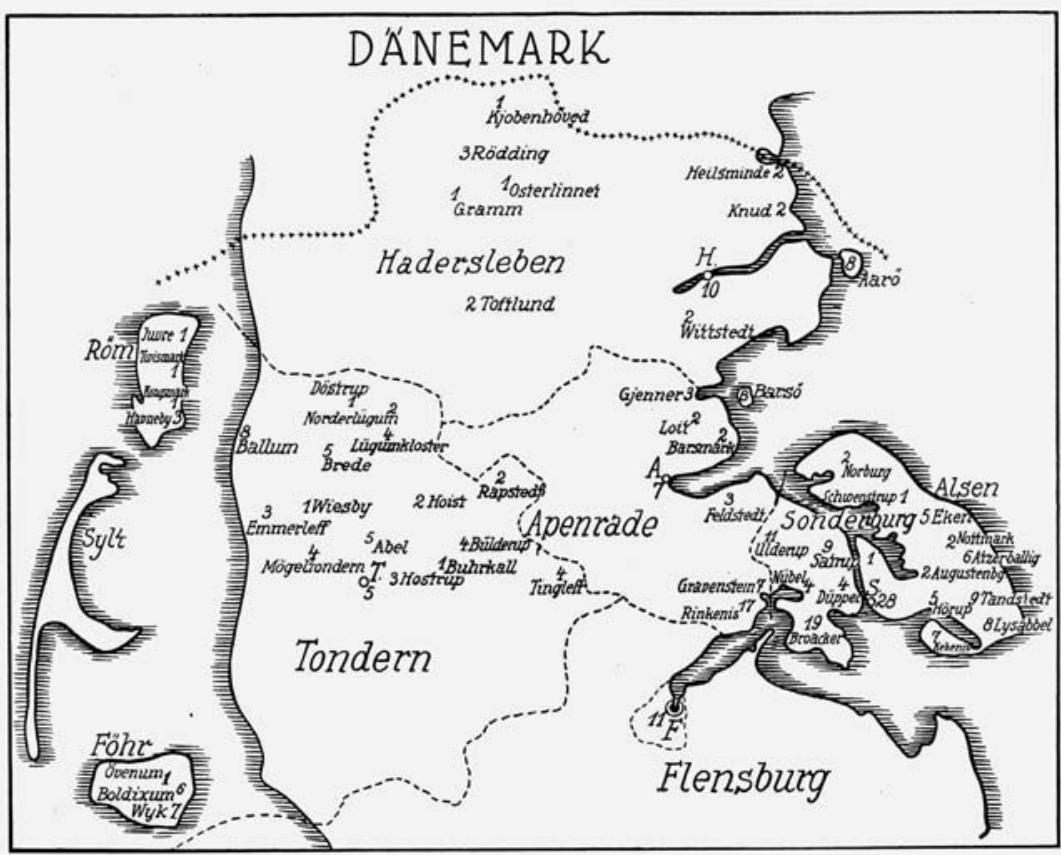

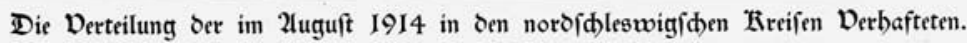

Kort over hvorfra i Nordslesvig de internerede dansksindede kom. Kilde: Karl Alnor 1927 , s. 820.

amtsfortander Kier i Sønderborg. Over halvdelen af dem, der blev arresteret i Sønderborg Amt kom fra hans sogne. «32 René Rasmussen har fulgt op ved på baggrund af Peter Kaads erindringer at konstatere, at hele 63 dansksindede blev arresteret i de otte sogne, hvor Kier var amtsforstander, mens der kun var syv arresterede i de seks nordalsiske sogne, hvor Klinker var amtsforstander. ${ }^{33}$ Det dansksindede medlem af den preussiske landdag, Nis Nissen fra Vibøge på Sydals, noterede noget tilsvarende i et privat brev til H.P. Hanssen, der er dateret 24.-27. august $1914 .{ }^{34}$ Han skrev blandt andet, at »vi må øvrigt indrømme, at Klinker med årene er bleven én af vore mest humane amtsforstandere. Vi har i år ikke haft en eneste tjenestebortvisning, og Peter Grau er - når Nic. Frederiksen, som har været uforsigtig med sin mund, undtages - den eneste, som blev arresteret ved krigens begyndelse i de tre nærmeste sogne; til sammenligning hermed kan anføres at P. Kier har omkring ved ti mand arresterede i hvert af de 


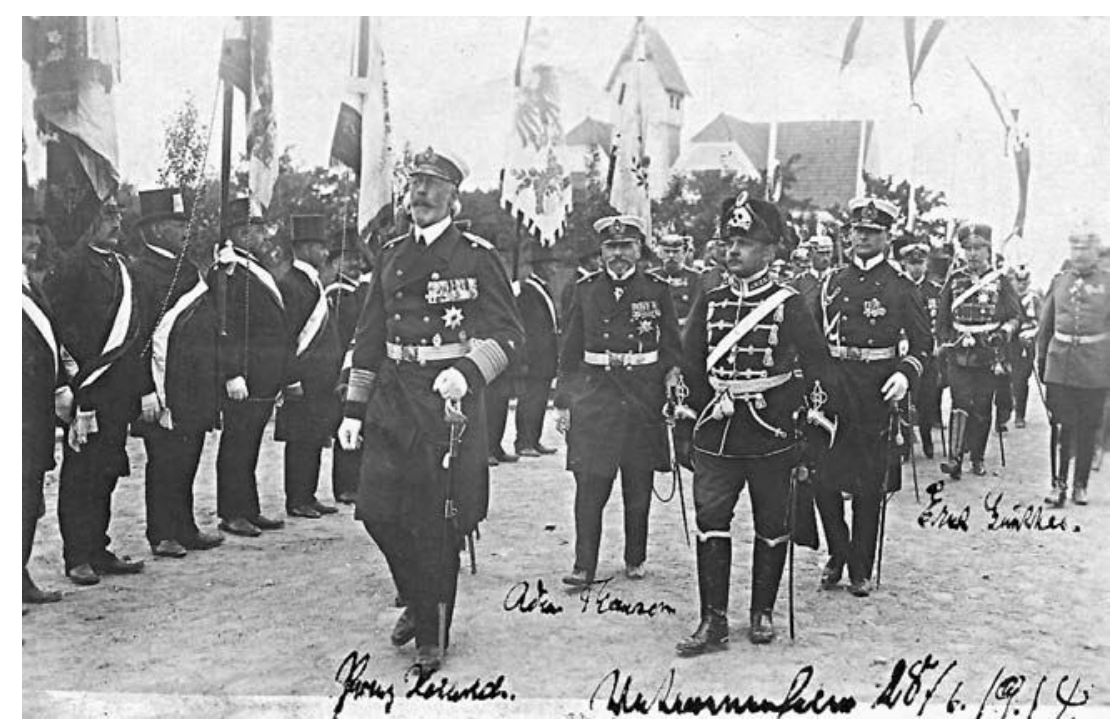

Postkort med motiv fra mindefesten på Dybbøl Banke den 28. juni 1914. På kortet ses bl.a. prins Heinrich af Preussen og landråd Curth Schönberg. Landråd Curth Schönberg $i$ Sønderborg Amt var den af de nordslesvigske landråder, der internerede langt flest. Han var en af den tysknationale bevægelses ledende skikkelser i Nordslesvig op til og under Første Verdenskrig. Museum Sønderjylland - Sønderborg Slot.

ham underlagte sogne på Als. Amtsforstanderne Jakobsen og Winkelmann har kun nogle få. «35

Ulkebøl var et også sogn i Sønderborg Amt, men her blev der kun arresteret en mand, nemlig Peter Kaad, der er nævnt ovenfor. Kaad forklarede dette med, at "vi havde i Ulkebøl Sogn en bosiddende gårdmand som amtsforstander, en mand, der vel var tysksindet, men som i modsætning til de indvandrede tyske amtsforstandere ikke så sin opgave i at forulempe sine undergivne, selv om de var danske, og min arrestation skyldes sikkert højere ordre. « ${ }^{36}$ Hans forklaring er væsentlig, og den virker ganske overbevisende. Amtsforstanderen i Ulkebøl, Andersen-Bagmose, var en lokal landmand, der åbenlyst ikke opfattede sine danske naboer som farlige agitatorer eller spioner. Derimod kan det være en forklaring på, at amtsforstandere, der ikke var lokale, men hentet fra Tyskland, oftere havde tendens til at gennemføre omfattende arrestationer. Dels fordi de havde en anden skoling end de lokale nordslesvigere, og dels fordi lokalkendskabet var mindre.

I Tønder var Emilio von Böhme i marts 1914 blevet udnævnt til 
landråd, og også han var jurist. Han var godsejersøn fra Oehe ved Kappel og havde altså dårligt nået at gøre sig bemærket i Tønder, inden krigen brød ud. ${ }^{37}$ O.D. Schack har i sine erindringer beskrevet Böhme nogenlunde positivt. Efter et besøg hos landråden den 2. august 1914 gav han ham følgende beskrivelse: »Böhme var kort tid forinden blevet ansat som landråd i Tønder og ganske ukendt med forholdene, hvorfor han i den allerførste tid mere end godt var rettede sig efter enkelte lokale tillidsmænd. Han var en meget anstændig og rettænkende mand. Vi blev senere ret gode venner. ${ }^{38}$ For Schack var det således klart, at det var de lokale amtsforstandere og de lokale politimyndigheder, der var hovedbagmændene bag arrestationerne i Tønder Amt. I forlængelse heraf må det betegnes som tvivlsomt, om Böhme overhovedet havde været med til at udarbejde arrestationslisterne, idet listerne formentlig var opstillet, inden han tiltrådte som landråd.

I en anden beretning skrevet af Thorvald Petersen i 1952, som også var blandt de internerede, citeres Böhme for den 2. august 1914 at skulle have sagt til de arresterede dansksindede: »Nå, endelig er den forløsende stund kommet. « ${ }^{39}$ Synet på Böhme var endnu mere kritisk - ja nærmest hadsk - i artiklen »Den tyske Landraad von Böhme«, der den 5. september 1919 blev bragt i den danske avis Hovedstaden. ${ }^{40}$ Baggrunden for artiklen var, at Böhme var bragt i spil som tysk repræsentant i Den internationale Kommission, der stod for at forberede og gennemføre folkeafstemningerne i Slesvig i februar og marts 1920. Det havde ifølge avisen »vakt den allerstørste forbitrelse og harme viden om. Det gælder selvfølgelig i særlig grad blandt de sønderjyder, som i årevis har måttet lide under hans hensynsløst brutale styre. Thi det kan siges uden overdrivelse: Hvad en von Köller gjorde af ondt mod den samlede slesvigske befolkning, det gjorde von Böhme i langt højere grad mod befolkningen i Tønder Kreds«. I artiklen henvises direkte til Böhmes ansvar for interneringen af dansksindede i Tønder Amt ved Første Verdenskrigs udbrud som baggrunden for denne svada.

I Tønder blev der interneret 20 farvandskyndige og 54 politiske fanger, hvilket var noget mindre end i Sønderborg, men en del højere end i Aabenraa og langt højere end i Haderslev. I forhold til de øvrige amter var der i Tønder en bemærkelsesværdig stor spredning med arrestationer ud over hele den del af amtet, der i dag er en del af Sønderjylland. I Sydtønder var det derimod kun på øen Før, at der 


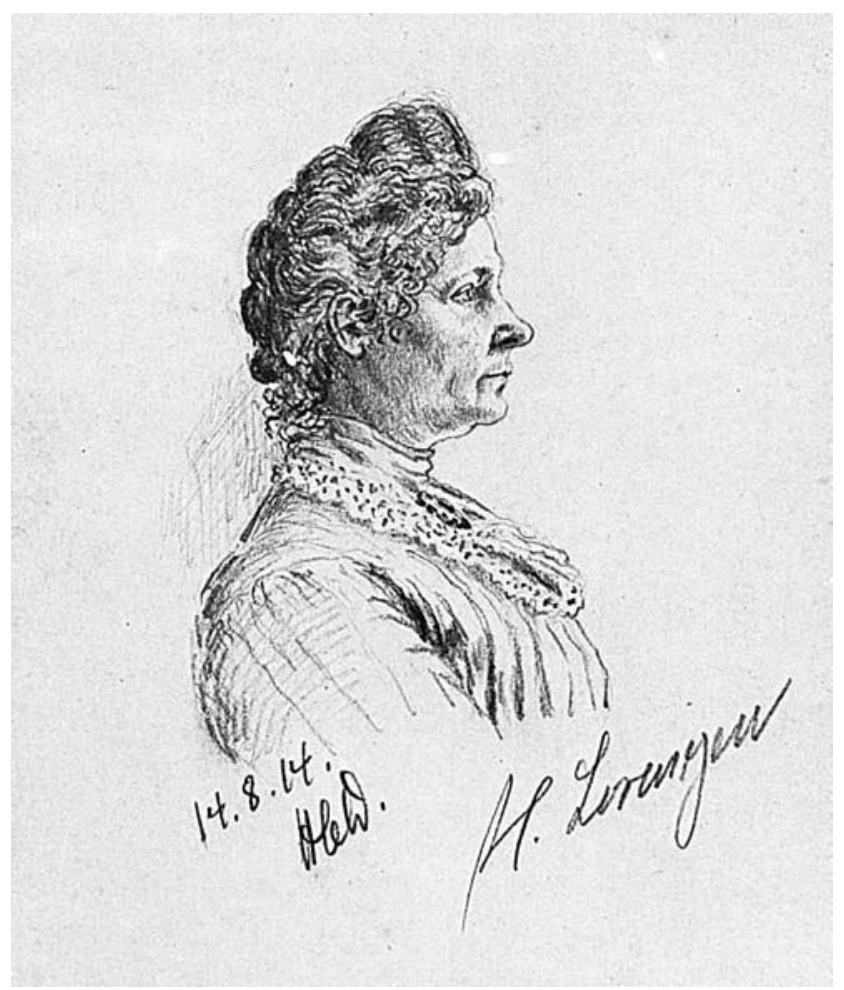

Tegning af Hansigne Lorenzen lavet af H.C. Davidsen i august 1914 under interneringen $i$ Flensborg. Hansigne Lorensen fra Ballum var én af få kvinder, der blev interneret. Hun var en kendt dansksindet forfatter, og hun blev interneret sammen med sin mand, Hans Lorenzen, og indsat $i$ det gamle gymnasium i Flensborg.

blev tvangsforflyttet 14 farvandskyndige, hvorimod der ikke blev interneret andre fra det nuværende Kreis Nordfriesland. ${ }^{41}$

I Aabenraa var Hans Siemon landråd. Han var tiltrådt i november 1913, så han var også helt grøn i embedet, da krigen brød ud. Derfor havde heller ikke han nået at gøre sig videre bemærket inden krigsudbruddet, og som det var tilfældet med Böhme i Tønder, er det tvivlsomt, om Siemon for alvor havde været involveret i at opstille den oprindelige arrestationsliste. Men at han følte, det var nødvendigt at arrestere journalisterne og redaktørerne på den dansksindede avis, Hejmdal - heriblandt H.P. Hanssen, der også var medlem af den tyske rigsdag - vidner et brev dateret 1. august 1914 fra Siemon til overpræsidenten om: »På baggrund af, at den danske presse, især Hejmdal, 
netop i den seneste tid har udtrykt en særlig tyskfjendtlig holdning [...] og havde propaganderet med tanker om løsrivelse og genforening med Danmark «, mente han, det var helt nødvendigt at forbyde Hejmdal og arrestere journalisterne og redaktørerne. ${ }^{42}$ Han forklarede også $\mathrm{i}$ brevet, at det var nødvendigt at internere den tyske socialdemokratiske leder i Aabenraa, murer Ewald, samt et par socialdemokratiske fiskere.

I de første dage af august 1914 sendte Siemon flere skrivelser til overpræsidenten. Han orienterede om, hvad der skete i amtet - herunder om arrestationen og frigivelsen af redaktørerne i Aabenraa men han virkede mildt sagt usikker på, hvad han skulle gøre og hvor langt han måtte gå. Han spurgte flere gange, om artikel 5 i den preussiske forfatning kunne sættes ud af kraft, hvilket han anså som vigtigt for, at han kunne følge generalkommandoens ordrer om at foretage interneringer. ${ }^{43}$ I denne artikel var det bestemt, at Forbundsrådet og Rigsdagen vedtog landets love, og kun i tilfælde af uenighed i Forbundsrådet $\mathrm{i}$ forbindelse med lovforslag af militær betydning var der nogle undtagelsesbestemmelser i forhold til denne hovedregel. Derfor bad Siemon overpræsidenten bekræfte, at artiklen var sat ud af kraft, da han tydeligvis mente, at det var forudsætningen for, at interneringerne af »unzuverlässige« kunne finde sted.

I det nordligste amt, Haderslev, blev der som nævnt ovenfor arresteret langt færre politiske fanger end i de øvrige sønderjyske amter. Blandt de 18 politiske fanger kom de ti fra Haderslev by, mens de øvrige arresterede var fordelt ud over hele amtet. Otte af de arresterede fiskere kom fra Årø ved indgangen til Haderslev Fjord. Landråden, Hugo Freiherr Löw von und zu Steinfurth, var kommet til Haderslev i 1908 og arbejdede frem til 1911 som assessor, hvorefter han blev landråd. I Harrebyes tendentiøse beskrivelse af von Löw, omtales han som en retfærdig mand, der formåede at sætte sig ind i befolkningens mentalitet. Hans arbejde og væremåde aftvang respekt af alle - også af den dansksindede del af befolkningen. ${ }^{44}$ I hvert fald henviser Harrebye til et takkebrev til von Löw, der blev trykt i den dansksindede avis i Haderslev, Modersmålet, den 17. januar 1920 i forbindelse med, at han forlod Haderslev. Takkebrevet blev angiveligt underskrevet af 1.500 dansksindede kvinder som tak for landrådens indsats for de dansksindede under Første Verdenskrig.

I Flensborg Amt blev der kun interneret ganske få mennesker. Alnor har noteret, at der blev arresteret syv politiske fanger og fire far- 
vandskyndige i Flensborg-området. Seks af de politiske fanger var tilknyttet Flensborg Avis - heriblandt redaktør Ernst Christiansen - og avisen blev desuden lukket den 11. august. I den statistiske opgørelse har Alnor alene regnet med politiske fanger fra Flensborg by, ligesom det af hans udarbejdede kort fremgår, at der i Flensborg var 11, som blev arresteret, men ingen i Flensborgs opland. Dog blev Peter og Henrik Lassen, der var far og søn og ejede den berømte Lassen-gård i Strukstrup i Angel, arresteret den 6. august og indsat i arresten i Slesvig, hvorfra de blev løsladt igen den 19. august. Der gik et rygte om, at de i det skjulte havde haft danske officerer indkvarteret, men en husundersøgelse kunne ikke verificere det, hvorfor de igen blev sat fri. ${ }^{45}$

\section{Avislukninger og arrestationer af journalister og redaktører}

Allerede den 31. juli 1914 blev Dannevirke i Haderslev lukket, og avisens journalister og redaktører blev arresteret. Redaktøren, N. Petersen, har siden forklaret, at Dannevirke blev »taget uden sværdslag ved hurtig overrumpling «, og at politiofficeren havde erklæret: »I kejserens navn er De anholdt. « Da jeg spurgte om grunden, svarede han, at han havde fået ordre til at arrestere mig, ransage huset, standse bladet og forsegle alle døre. « ${ }^{46}$ Udenfor i Haderslevs gader var journalisterne Anders Lebeck og Jes Sarup blevet arresteret, mens den aldrende redaktør, M.C. Matthiesen, blev afhentet i sit hjem. ${ }^{47}$ Alle blev indsat i politifængslet i Haderslev. Dannevirkes sidste medlem af redaktionen, Nicolai Svendsen, var på familiebesøg i Rejsby, og den 1. august rejste han med toget til Skærbæk. Her blev han arresteret af amtsforstander Erichsen, og efter at have fået lov til at spise frokost med sin familie, blev han indsat i arresten i Skærbæk. ${ }^{48}$ Dannevirke i Haderslev blev således lukket umiddelbart efter krigsudbruddet, og avisens journalister og redaktører var blandt de første dansksindede, der blev arresteret.

Dagen efter - lørdag den 1. august - blev Dybbøl-Posten i Sønderborg lukket. Redaktøren, Adolph Svensson, har forklaret, at han efter en forhandling med byens borgmester og politimester, dr. Petersen, måtte lukke avisen og udsende en løbeseddel med ordlyden: »Efter krigstilstanden er blevet proklameret, og dagbladene kun kan udkomme med politiets tilladelse, er Dybbøl-Posten fra i dag blevet 
standset af myndighederne. Ud over denne meddelelse vil vore læsere foreløbig ikke høre mere fra bladet. « ${ }^{49}$ Svensson og avisens øvrige redaktion og journalister blev dog først arresteret to dage senere og indsat i amtsretsfængslet i Sønderborg den 3. august 1914. ${ }^{50}$

I Aabenraa fik Hejmdal lov til at udkomme frem til den 8. august 1914, selv om redaktørerne Niels Hansen og J. Frost ligesom H.P. Hanssen blev arresteret den 31. juli. ${ }^{51}$ H.P. Hanssen var også medlem af den tyske rigsdag, og han var altså blandt de første, der blev arresteret. Af hans dagbog fremgår, at arrestationen fandt sted kl. 21, og at han blev indsat i arresten ved amtsretsfængslet i Aabenraa. Der sad også hans to medredaktører. Næste morgen ved 8-tiden fik han overrakt en indkaldelse til et møde i Rigsdagen den 4. august, hvorefter han skrev en kraftig protest over sin arrestation, der ville forhindre ham i at møde op i Rigsdagen. Protesten blev via landråd Siemon sendt til den kommanderende general i Altona, von Roehl, og allerede kl. 14 samme dag modtog H.P. Hanssen sin frigivelse. I brevet, der var underskrevet af landråd Siemon, er det noteret: »Den kongelige generalkommando har på min opfordring erklæret sig indforstået med, at De straks frigives fra den i går iværksatte arrestation, hvorved det vil være muligt for Dem at deltage i de forestående forhandlinger i den tyske rigsdag. « ${ }^{52}$ Dermed var Hanssen ikke blot en af de første, der blev arresteret - han var også den, der blev først frigivet.

De to medredaktører blev også løsladt igen den 1 . august, men de blev tvunget til at underskrive en erklæring om, at »vi intet vil foretage os til skade for mobiliseringen og Tysklands interesser «, hvilket de gerne gjorde, fordi »vi havde jo ingen onde hensigter«, som Niels Hansen har udtrykt det. ${ }^{53}$ Hejmdal fik ikke lov til at udkomme i normalt format i dagene efter krigens udbrud, idet den kun udkom som »censureret løbeseddel « den 5. august, i halvt format den 6. august, mens den udkom i fuldt format den 7. og 8. august. ${ }^{54} \mathrm{Om}$ aftenen den 8 . august ved 22-tiden mødte en preussisk kaptajn op hos H.P. Hanssen og meddelte ham, at Hejmdal var forbudt efter ordre fra den kommanderende general von Roehl. ${ }^{55}$ Hanssen sendte dagen efter en protest til von Roehl og anmodede samtidig om at få lov til at udsende danske oversættelser af den tyske hærledelses officielle telegrammer, der blev udsendt af Wolff's Telegraphisches Bureau. Da han ikke havde modtaget svar, trykte han sådanne oversatte telegrammer, som blev hængt op rundt om i Aabenraa den 10. august. Resultatet var, at han blev kaldt op til politimesteren, der kunne oply- 
se, at landråd Siemon havde forbudt ophængning af den slags danske oversættelser. ${ }^{56}$

Flensborg Avis fik lov til at udkomme frem til den 11. august, men blev derefter forbudt, samtidig med at "pressefriheden blev ophævet i Nordslesvig samt i Flensborg by- og landkreds «. ${ }^{57}$ I en artikel fra den 28. august 1914, hvor Flensborg Avis og de øvrige dansksindede aviser igen var begyndt at udkomme, blev det forklaret, at avisen indtil lukningen alene havde skrevet om »efterretnings- og underholdningsstof «, og at man kun havde bragt officielle telegrammer fra Wolff's Telegraphisches Bureau. Avisen fandt det afgørende, at »alle de nordslesvigske forældre, som uden undtagelse og uden tøven havde fulgt indkaldelsen, havde krav på at få tabslister, bekendtgørelser og krigsefterretninger at læse i et for dem forståeligt sprog. At dette skete var også i myndighedernes interesse. «58

I Flensborg Avis' artikel fra slutningen af august 1914 blev det på få linjer gjort klart, at avislukningerne af mindst to grunde var problematiske. Den ene grund var, at samtidig med at de danske aviser blev forbudt - og dansksindede nordslesvigere arresteret - var mange tusinde unge dansksindede mænd blevet indkaldt som tyske soldater. Den anden grund var, at de mange pårørende i Nordslesvig havde krav på at få underretninger på dansk om krigens gang, herunder om tabslister og bekendtgørelser. Derfor blev der gennem flere uger ført en kamp mellem de danske avisudgivere og generalkommandoen om, at aviserne igen skulle udkomme på dansk - ikke på tysk som krævet af de tyske myndigheder. Det var de samme argumenter, H.P. Hanssen benyttede i sin protest, som blev sendt til den kommanderende general dagen efter, at Hejmdal var blevet forbudt, og som han i øvrigt vedblev med at fremføre over for de tyske myndigheder i ugerne efter krigens udbrud. ${ }^{59}$

Da aviserne igen fik lov til at udkomme på dansk i slutningen af august 1914, skete det under skarp censur. H.P. Hanssen måtte underskrive en erklæring udfærdiget af landråd Siemon om, at politimyndighederne i Aabenraa først skulle gennemlæse avisen, inden den blev sendt på gaden. Han måtte også acceptere følgende indskrænkninger i, hvad avisen måtte skrive om: »Avisledelsen må for at undgå et umiddelbart forbud af avisen kun bringe offentlige nyheder fra krigsskuepladserne og om krigen generelt. Agitatoriske artikler og tilsvarende upatriotiske tyskfjendtlige eller artikler af hadefuld karakter mellem de forskellige befolkningsgrupper vil straks have til følge, 
at avisen forbydes. ${ }^{60}$ Lignende pålæg fik de øvrige dansksindede aviser i Slesvig, og der er flere eksempler på, at aviserne i løbet af krigen i kortere perioder fik forbud mod at udkomme, fordi myndighederne mente, at de havde overtrådt censuren.

I forbindelse med at de danske aviser igen kunne udkomme på dansk omkring den 28. august 1914, var der flere af de tysksindede aviser i Nordslesvig, der udtrykte harme over, at de danske aviser igen var på gaden. Det bedst kendte eksempel er Sonderburger Zeitung, der i en artikel den 5. september gav udtryk for, at forbuddet var nødvendigt: »Dette, at protestpressen ikke har kunnet udkomme, er ikke blevet følt som en mangel i Nordslesvig. Som det har været tilfældet med tyskerne, sådan har også de dansksindede nordslesvigere formentlig åndet op, da trykket af agitationen fra ophidsningspressen blev taget fra dem. « 61

\section{H.P. Hanssens indsats i Berlin}

H.P. Hanssen har i sine dagbogsnotater lagt stor vægt på, at han kæmpede bravt for at få frigivet de dansksindede fanger og ophævet avisforbuddet. Han blev som nævnt arresteret allerede den 31. juli 1914 og frigivet igen dagen efter. Arrestationen af ham må betragtes som en alvorlig fejl begået af de lokale tyske myndigheder - det vil sige landråd Siemon, overpræsident von Bülow og kommanderende general von Roehl. Arrestationen var en klar overtrædelse af hans immunitet som medlem af Rigsdagen, og det må betegnes som en slem begmand, at han blev frigivet under et døgn efter, at han blev arresteret. Efter frigivelsen arbejdede han meget aktivt for at få frigivet de øvrige arresterede, hvilket blandt andet illustreres af, at han ifølge dagbogen rejste til Berlin mindst ni gange fra begyndelsen af august 1914 til slutningen af december samme år, heraf alene tre gange i løbet af august og to gange i september. ${ }^{62}$ Desuden førte han tæt korrespondance med flere af sine rigsdagskolleger, der af forskellige omgange fremførte hans ønsker og krav over for medlemmer af regeringen, primært indenrigsminister Friedrich Wilhelm von Loebell og udenrigsminister Gottlieb von Jagow.

Dagen efter sin løsladelse rejste H.P. Hanssen til Berlin, hvor han ankom om aftenen den 2. august. I løbet af den 3. og 4. august mødtes han med en lang række nære rigsdagskolleger, blandt andet den senere socialdemokratiske indenrigsminister, Rudolf Breitscheid, der også 


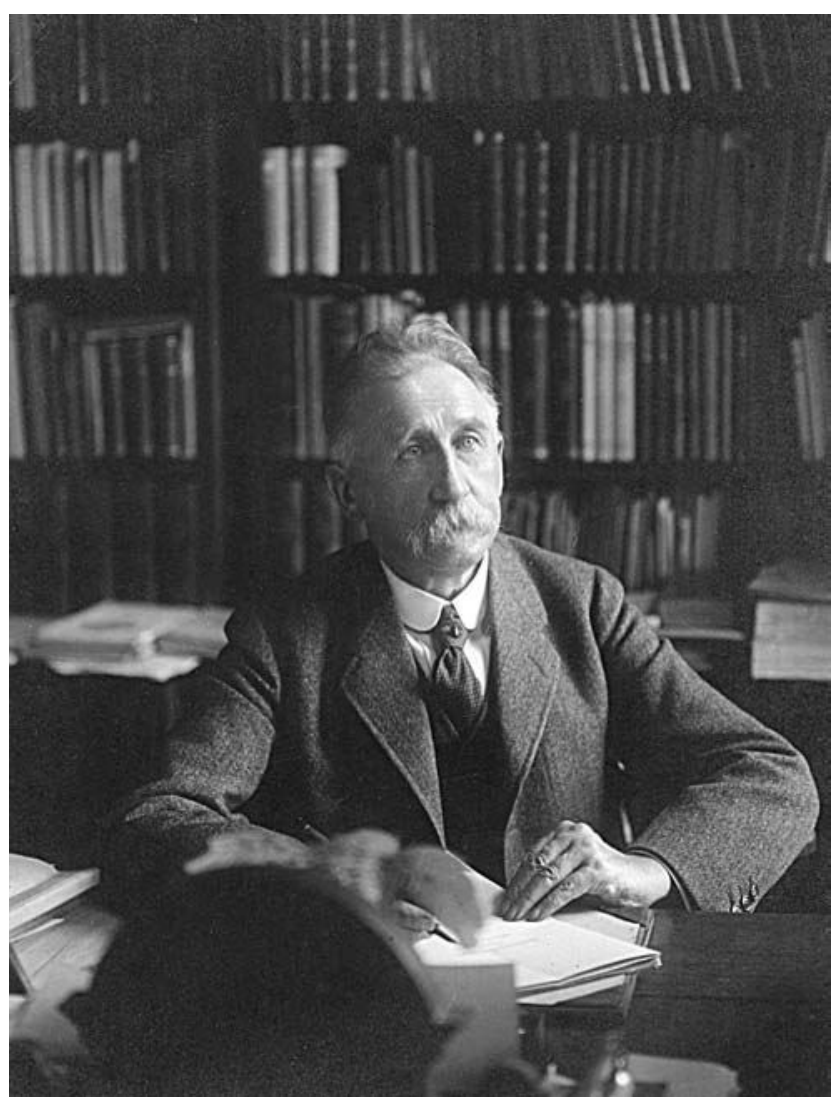

Portræt af Hans Peter Hanssen fra 1932. H.P. Hanssen var medlem af den tyske rigsdag og udgiver af avisen Hejmdal. I august og september 1914 havde han afgørende betydning for, at de internerede dansksindede blev frigivet, og at de dansksindede aviser igen kunne udkomme på dansk. Foto: Arkivet ved Dansk Centralbibliotek for sydslesvig.

havde været arresteret kort tid mistænkt for at være serbisk spion. ${ }^{63}$ Skal man tro dagbogen, havde H.P. Hanssen meget tæt kontakt til en række højtstående liberale og socialdemokratiske rigsdagsmedlemmer, hvilket var af stor betydning for, at han kunne få sine budskaber viderebragt til regeringen. Og det var igen afgørende for, at regeringen vidste, hvad der skete i Nordslesvig. Dagbogen har et vist præg af, at den er skrevet af en mand, der tillagde sin egen indsats i disse første krigsuger meget stor betydning, men der er meget, der tyder på, at han faktisk havde ret i vurderingen af sin egen indsats. I hans 
arkiv på Landsarkivet er der bevaret en ganske omfattende korrespondance, der i vid udstrækning bakker hans dagbogsudtalelser op, og som stemmer overens med afskrifterne af breve og andre dokumenter, der findes i udgivelsen af dagbøgerne. ${ }^{64}$ Det er ikke sandsynligt, at frigivelsen af de dansksindede og genåbningen af aviser alene skyldes hans indsats, men det har utvivlsomt været stærkt medvirkende til at speede processen op.

I et første udkast til sine erindringer, der er skrevet i 1916, har O.D. Schack noteret: »Den andel, H.P. Hanssen har i vores og særligt i min løsladelse, og den store tak, jeg skylder ham, er ikke tilnærmelsesvis antydet. Min korrespondance giver nogen oplysning om hans virke. Måske vil grundig fremstilling deraf først være mulig og rådelig efter krigen. « ${ }^{65}$ Der er således ingen tvivl om, at i hvert fald Schack tillagde H.P. Hanssen en afgørende betydning for, at han selv var blevet frigivet, men i øvrigt for frigivelserne generelt.

Hanssen anfører i dagbogen, at han den 4 . august sad sammen med flere rigsdagskolleger, da ministerialdirektør i Indenrigsministeriet, Theodor Lewald, i alles påhør havde udtalt: »Indenrigsminister von Loebell har pålagt mig at udtale over for Dem ministeriets dybe beklagelse over, at De har været arresteret. Arrestationen er foretaget uden regeringens vidende og meget imod dens vilje. Regeringen beder Dem derfor om at undskylde det skete. « ${ }^{66}$ Dermed var H.P. Hanssen klart foran på point. Han forstod at udnytte, at indenrigsministeren var blevet opmærksom på, at der foregik en undertrykkelse af de dansksindede slesvigere, hvilket han i dagene inden krigens udbrud netop havde understreget ikke måtte finde sted.

Under sit korte ophold i Berlin har Hanssen øjensynligt ikke haft noget nærmere kendskab til, hvordan forholdene i Nordslesvig udviklede sig. I hvert fald beskrev han, at det forst var sidst på eftermiddagen den 6. august - efter en langsommelig togtur hjem - at han fik underretning om, hvad der var sket i mellemtiden: »Jeg fik fat $\mathrm{i}$ Flensburger Nachrichten og læste, at mange sønderjyder er blevne fængslede, mens jeg har været borte. Af navnelisterne så jeg, at de fleste danske journalister er arresterede. Endvidere nævnes P. Grau, Dr. Sarauw, grev Schack, P. Kaad, P.A. Callø. Min broder og tre af mine svogre er også blandt de arresterede. Jeg vil nu hurtigst muligt se at få fuld klarhed tilvejebragt. $\ll^{67}$

I de følgende dage indsamlede H.P. Hanssen navne på de internerede. Under den 7. august noterede han i dagbogen, at »I al stilhed har 
jeg i dag udsendt tillidsmænd til de forskellige amter for at indsamle sikre efterretninger om de arresterede «, og fire dage senere er der skrevet: »jeg havde indsamlet ret omfattende oplysninger om de arresterede og ligeledes om den øvrige presses stilling. «68 På det grundlag kunne han den 11. august sende et brev til sin rigsdagskollega, Friedrich Naumann, der var en førende liberal politiker med gode kontakter til det regerende nationalkonservative parti. ${ }^{69} \mathrm{I}$ brevet henviste han til, at han under sit ophold i Berlin ved Rigsdagens samling i begyndelsen af august havde fået det indtryk, at Naumann delte Hanssens kritik af undertrykkelsen af de danske nordslesvigere, og at han anså det som ukloge foranstaltninger. Hanssen skrev i klar tekst, at alle danske blade i Nordslesvig var forbudt, og at mere end 200 danske nordslesvigere var interneret. Det skete samtidig med, at 15.-16.000 unge danske mænd deltog i krigen som tyske soldater, ligesom mange af de internerede havde flere sønner, der var blevet indkaldt. Hanssen udtrykte, at der absolut ikke forelå nogen kendsgerninger, der retfærdiggjorde arrestationerne, og han sluttede af med at notere: »Arrestationerne har den uheldigste indflydelse på stemningen i Nordslesvig. Og så snart disse drakoniske forholdsregler bliver bekendt i Danmark og i Skandinavien, vil de utvivlsomt vække den dybeste misstemning imod og mistillid til Tyskland. Det skader faktisk i disse kritiske tider i høj grad rigets interesser. «"

Derfor bad H.P. Hanssen Naumann om at oplyse regeringen om forholdene i Nordslesvig, og to dage senere modtog han to depecher fra Naumann, hvor denne dels bekræftede modtagelsen og dels bekræftede, at han ville gøre, hvad han kunne for at få viderebragt Hanssens oplysninger de rigtige steder. ${ }^{71}$ Nogle dage senere - den 15. august - oplyste Naumann, at han efter modtagelsen af H.P. Hanssens brev havde ladet det afskrive og derefter var gået til Udenrigsministeriet, hvor han over for udenrigsminister von Jagow havde givet sin mening til kende. Udenrigsministeren havde givet udtryk for, at han misbilligede de ting, der foregik i Nordslesvig, og at han »straks ville sætte sig i bevægelse for at få de begåede fejlgreb rettede. $\ll^{72}$

Naumann skrev et nyt brev dateret 15 . august, hvor han noterede, at rigskansler Theobald von Bethmann Hollweg lagde megen vægt på, at oplysningerne i H.P. Hanssens brev af den 11. august kunne bekræftes. ${ }^{73}$ Hanssens protester var dermed nået op på det højeste niveau, men som Naumann gjorde tydeligt opmærksomt på, havde man i Ber- 
lin kun kendskab til en enkelt arresteret - nemlig H.P. Hanssen selv hvorfor "påstanden i Deres brev, at 200 danske nordslesvigere er arresterede, synes opdigtet «. Derfor bad Naumann om, at Hanssen straks telegraferede en bekræftelse på, at der rent faktisk var interneret mange danske nordslesvigere, og at han samtidig nedskrev navne og steder på alle dem, han havde kendskab til, som sad arresteret.

I sit svar samme dag skrev H.P. Hanssen, at »mine angivelser opretholdes i et og alt«. Han opfordrede også til, at der blev sendt officielle forespørgsler til landråden i Sønderborg og til politiforvaltningen i Flensborg. Han vedlagde desuden en liste med navnene på 102 internerede, hvor også erhverv og bopæl fremgik, og han uddybede med at oplyse, at 1) der nu sad omkring 80 interneret på Sønderborg Slot, 2) at 32 arresterede i Haderslev Amt var transporteret til Rügen, 3) at 46 fra Tønder Amt ugen forinden var sendt til Altona, hvorfra de igen var frigivet, og 4) at omkring 30 fra Flensborg og Tønder Amter nu sad indespærret på en skole i Flensborg. I forlængelse heraf noterede Hanssen, at alle danske aviser i Nordslesvig var forbudt. ${ }^{74}$ Som det fremgår nedenfor, var Hanssen ikke fuldt opdateret, idet der på dette tidspunkt var flere internerede rundt om i Nordslesvig og Flensborg, men det var ikke så afgørende. Det vigtige var, at Naumann hurtigt kunne underrette regeringsledelsen om, at der i Nordslesvig - mod regeringens vidende og ønske - var foretaget omfattende interneringer af dansksindede og gennemført forbud mod de danske aviser.

I sit svarbrev dateret 19. august 1914 oplyste Naumann, at han straks var gået til Indenrigsministeriet med H.P. Hanssens brev og liste. Indenrigsministeren takkede for oplysningerne og havde udtalt, at »Regeringen indtager det klare og tydelige standpunkt, at alle såkaldte præventivforanstaltninger, arrestationer af frygt for, hvad der kan ske, avisforbud uden bestemt foranledning og lignende misbilliges, og der er givet streng ordre til herefter at gennemføre disse grundsætninger «. ${ }^{75}$

I de følgende dage modtog H.P. Hanssen breve fra andre rigsdagskolleger, der opfordrede ham til at komme til Berlin snarest. Én af brevskriverne var Matthias Erzberger, som var ledende politiker for det nationale katolske parti Zentrum, ligesom han havde været redaktør af den konservative avis Deutsches Volksblatt. Kort efter krigsudbruddet blev Erzberger leder af en komité, der stod for den tyske udlandspropaganda, og det var grunden til, at han kontaktede H.P. Hanssen. I brevet gjorde han det klart, at han ønskede at bruge 
Hejmdal og andre danske aviser i Nordslesvig til at bringe »absolut garanterede nyheder « i mediekampen med britiske og franske aviser om udlægningen af krigens forløb, ligesom han bad Hanssen om at oplyse, hvilke danske aviser der ville være interesseret $i$ at bringe den type tyske nyheder. ${ }^{76}$

En anden af brevskriverne var Rudolf Breitscheid, der kort og godt bad Hanssen om at komme til Berlin snarest, men uden at begrunde, hvorfor det var så vigtigt. Breitscheids brev afsluttedes med "Mit herzlichem Gruss, Ihr. Rud. Breitscheid «, hvilket klart antyder, at han og H.P. Hanssen havde et godt personligt forhold til hinanden. Hanssen mødtes med Breitscheid, umiddelbart efter han ankom til Berlin den 24. august, og »Grunden til, at han havde kaldt mig til Berlin var, at man i ledende kredse nærede megen frygt for, at Danmark ikke ville eller kunne opretholde sin neutralitet i længden «. ${ }^{77}$ Henvendelsen antyder, at Breitscheid var sendt i byen af Udenrigsministeriet, for at man fra tysk side kunne bruge Hanssen til - via sine tætte politiske kontakter i Danmark - at overbevise den danske regering og den danske rigsdag om, at det var afgørende, at Danmark forblev neutral under krigen.

Selv om de tre ting - Danmarks neutralitet, ønsket om at bringe officielle tyske nyheder i danske aviser og de tyske myndigheders behandling af de dansksindede i Slesvig - ikke umiddelbart hang sammen, så gjorde de det alligevel. I hvert fald lykkedes det for H.P. Hanssen at gøre det klart, at man fra tysk side dårligt kunne forvente, at danske aviser ville skrive noget positivt om Tyskland, så længe mange danske slesvigere var interneret og aviserne forbudt. Det skinner også igennem, at selv om han nok mente, at det var i dansk interesse, at landet blev holdt ude af krigen, så ville han ikke lade sig bruge som tysk sendebud og informant, hvis ikke der kom en snarlig afklaring i Nordslesvig.

På et møde den 24. august mellem H.P. Hanssen og indenrigsminister von Loebell udtalte sidstnævnte igen, at præventive interneringer og avislukninger ikke ville blive accepteret, og at det ikke havde været hensigten ved krigsudbruddet. Problemet var ifølge ministeren forholdet mellem de militære og de civile myndigheder. Von Loebell fortsatte med at udtale, at forholdene nu ville blive bedre, fordi »Overpræsident v. Bülow træder tilbage, og statsminister v. Moltke er udnævnt til overpræsident $\mathrm{i}$ hans sted. Den nye overpræsident vil gennemføre mine grundsætninger: Ingen præventivforbud. Fangerne 
skal sættes på fri fod. Aviserne kan atter udgå på dansk «. ${ }^{78}$ Tager man citatet for pålydende betyder det altså, at overpræsident von Bülow blev fyret på grund af den linje, der blev ført mod de danske slesvigere i de første uger efter krigens udbrud. En linje, der ikke blev billiget af indenrigsministeren og regeringen, og som von Bülow øjensynligt ikke indberettede noget om til Berlin.

Indenrigsministeren forsøgte rent faktisk at sætte sig igennem over for generalkommandoen, overpræsidenten og landråderne. Da han havde fået underretning om H.P. Hanssens arrestation sendte han igen et brev til overpræsidenten om, at regeringen ikke ønskede, der blev foretaget præventive arrestationer og avislukninger, men det hjalp ikke stort. Den 15. august berettede regeringspræsident Ukert fra Slesvig fra et møde i Flensborg dagen forinden mellem overpræsidenten og landråderne, som blev sendt til indenrigsministeren. Alle var enige om, at »det nuværende tidspunkt ikke var velegnet til at gøre sig overvejelser om at løslade de internerede agitatorer og til at ophæve forbuddet mod de danske aviser. «79 Ukert udtrykte også en fælles bekymring over, at H.P. Hanssen var på fri fod, idet man anså ham som farlig.

Indenrigsministeren sendte den 22. august et brev til generalkommandoen i Altona - med genpart til overpræsidenten - hvor han klart linede sin og regeringens politik op med hensyn til de dansksindede i Slesvig. ${ }^{80}$ Alle internerede skulle frigives snarest, og aviserne skulle igen have lov til at udkomme på dansk. Til gengæld skulle de frigivne følges tæt, der skulle gennemføres brev- og telefoncensur, og der skulle være omfattende kontrol med danske aviser i Nordslesvig.

Den nyudnævnte overpræsident videresendte den 26. august 1914 disse instruktioner fra indenrigsministeren til landråderne. Da det samtidig lykkedes at få generalkommandoen til at acceptere disse instruktioner, blev der afholdt et nyt møde i Flensborg, hvor overpræsidenten mundtligt fortalte landråderne om indenrigsministerens retningslinjer. ${ }^{81}$ Samtidig oplyste overpræsidenten, at de frigivne fanger ikke længere skulle underskrive erklæringer, men alene klart have at vide, hvilke konsekvenser det ville have, hvis de optrådte tyskfjendtligt eller havde kontakt til udlandet.

På mødet med indenrigsministeren den 24. august kvitterede H.P. Hanssen med at sige, at en gennemførelse af disse grundsætninger ville berolige stemningen i Nordslesvig. Samtidig udtalte han, at der allerede var »18.-20.000 danske nordslesvigere i felten«, og at »alle 
disse nordslesvigere betragter det som den forfærdeligste ulykke at skulle kæmpe imod deres egne landsmænd og folkefæller. I Nordslesvig ønsker alle derfor, at Danmark vedblivende skal opretholde sin strenge neutralitet $\ll .82$

Naumann deltog på mødet, og han var som Erzberger engageret i den komité, der stod for den tyske udenlandspropaganda. Han understregede over for indenrigsministeren, at de danske aviser i Slesvig var blevet lukket, og at det endda var forbudt at ophænge danske oversættelser af officielle krigsefterretninger fra Wolff's Telegraphisches Bureau. Det så han tydeligvis som en hæmsko for, at man fra tysk side - via H.P. Hanssen - kunne få danske aviser til at bringe tyske krigsnyheder. På et efterfølgende møde i Rigsmarineamtet - hvor Naumann også deltog - blev Hanssen spurgt om, hvordan stemningen i Danmark kunne blive mere gunstigt stemt for Tyskland, hvortil han svarede, at det afgørende ville være gode efterretninger fra Nordslesvig: »Støt mine bestræbelser på at få fangerne fri, og udsend straks efterretningerne derom gennem Wollf's Bureau. Det vil påvirke stemningen i positiv retning. $^{83} \mathrm{Da}$ han vendte tilbage til sit hotel, lå der underretning fra generalkommandoen i Altona om, at Hejmdal og Flensborg Avis igen kunne udkomme, men kun på tysk. Det fik ham til at sende et telegram hjem til redaktionen på Hejmdal om, at der ikke måtte udgives aviser, inden han var tilbage. Det gjaldt også for Flensborg Avis. ${ }^{84}$ Dermed ville han forhindre, at de danske aviser begyndte at udkomme på tysk, inden indenrigsministerens instrukser om, at de igen kunne udkomme på dansk, nåede frem til den nye overpræsident i Slesvig.

H.P. Hanssen nåede dårligt tilbage til Aabenraa den 27. august 1914, inden han rejste tilbage til Berlin dagen efter. Han fik dog underskrevet ovennævnte erklæring skrevet af landråd Siemon, hvorefter Hejmdal igen kunne udkomme på dansk. Tilbage i Berlin havde han et møde med Erzberger den 29. august, hvor formålet var at få Hanssen til at arbejde for, at danske aviser ville bringe lige så mange positive tyske krigsefterretninger, som de bragte britiske og franske. Hanssen lod klart forstå, at der i Danmark var en udpræget vilje til at opretholde neutraliteten, men at befolkningens sympatier overvejende lå hos Vestmagterne - «og Preussens voldspolitik i Nordslesvig har vakt dybtgående uvilje«. På mødet fandt en form for handel sted; Erzberger var interesseret $i$ at få at vide, hvad der skulle til for at få aviserne til at "påvirke stemningen i Danmark i en for os gunstig retning?«. Dertil svarede 
Hanssen "gode efterretninger fra Nordslesvig. Skaf mig hurtigst muligt fangerne fri. [...] Intet vil momentant påvirke stemningen bedre. ${ }^{85} \mathrm{Til}$ gengæld lovede han, at hvis Erzberger kunne klare det, så ville han til gengæld skaffe nogle gode kontakter til danske aviser.

Det interessante er i denne sammenhæng, at H.P. Hanssen i dagene før sin afrejse til Berlin den 23. august 1914 og under sit ophold i byen den 24 . og 25 . august og igen den 27 . august til den 1 . september fik knyttet vigtige kontakter til nogle centrale beslutningstagere, der havde en fælles interesse i af få klaret problemerne for de dansksindede i Slesvig. Dels fordi interneringerne og avisforbuddene forhindrede en god kontakt til Danmark og de danske aviser, og dels fordi det kunne være med til at bedre mulighederne for, at Danmark ville forblive neutralt under krigen. De første underretninger den 30. august om, at de internerede fra Haderslev og fire internerede fiskere i Flensborg var blevet frigivet, var helt klart medvirkende til, at Hanssen også aktivt søgte at skabe positive kontakter til danske aviser. Og lige inden han tog tilbage til Aabenraa den 1. september, oplyste Erzberger, at indenrigsminister von Loebell havde givet den nye overpræsident i Slesvig, von Moltke, ordre til personligt at rejse rundt til landråderne og instruere dem om, at de internerede dansksindede skulle frigives straks. ${ }^{86}$

\section{Interneringer og frigivelser}

Langt de fleste internerede blev samlet i Sønderborg og Flensborg, og hovedparten blev frigivet mellem den 20. august og den 12. september 1914. Det gælder dog ikke for Aabenraa Amt, hvor de internerede blev løsladt umiddelbart efter arrestationerne. Det er de overordnede kendetegn i forbindelse med interneringerne af de dansksindede slesvigere, men der var samtidig tale om meget forskellige forløb i de fem forskellige amter.

Alle fangerne i Sønderborg Amt blev samlet i Sønderborg, men enkelte af fangerne fra oplandet blev først indsat kort tid i lokale arresthuse, inden de blev sendt videre. I dagene efter den 1. august blev Sønderborghus benyttet som interneringssted. Sønderborghus var åbnet i maj 1914 som dansk forsamlingshus, og flere af de internerede har efterfølgende kommenteret $i$ deres erindringer, at det var trist at se netop dette sted benyttet som fængsel. Forpagteren $\mathrm{Chr}$. Nielsen har beskrevet, hvordan tyske soldater havde overtaget Sønder- 


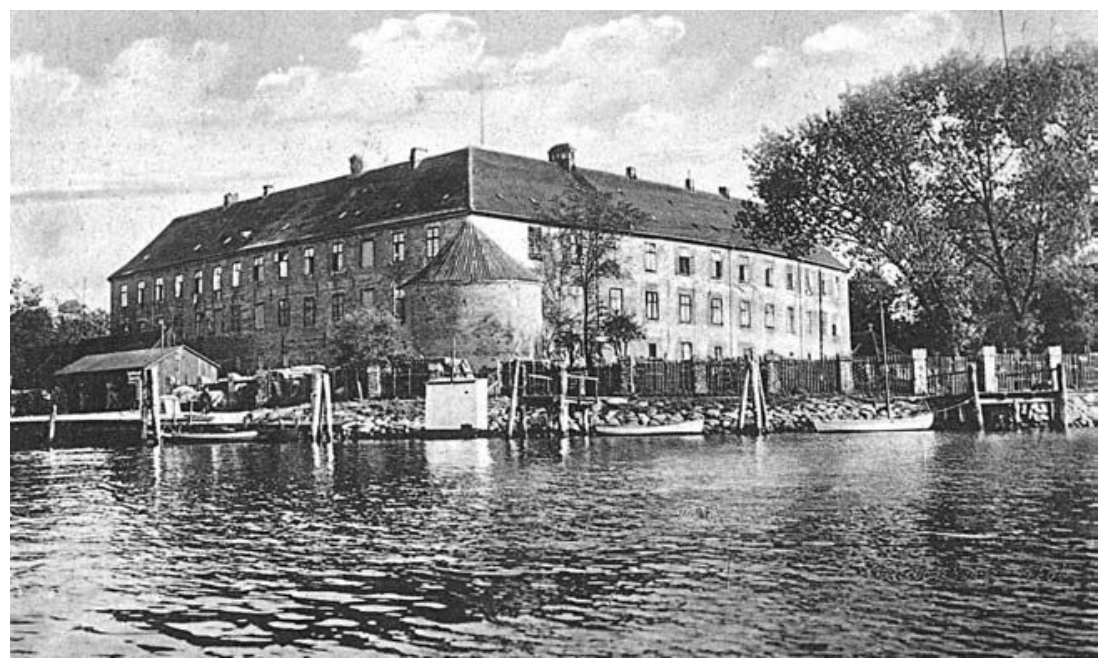

Postkort med Sønderborg Slot, udgivet af P. Biehl, Sønderborg. Der var en overgang interneret næsten 130 mennesker på Sønderborg Slot. Dermed var mere end halvdelen af alle de indespærrede dansksindede slesvigere interneret på slottet. Foto: Museum Sønderjylland - Sønderborg Slot.

borghus den 1. august, mens han selv havde været væk nogle timer. Han blev tvunget til at aflevere nøglerne og fik at vide, at der ville komme fanger i løbet af natten. ${ }^{87}$ Natten mellem den 1. og 2. august blev Nielsen banket op, og fik ordre om at skaffe plads til »de gode danske mænd fra Sundeved. Mænd som Joh. Andresen, Ullerup, Jørgen Zachariassen, Dybbøl, Kr. Iversen, Avnbøl, Jørg. Mathiesen, Græshøj m.fl.«, som stod udenfor. Fangerne blev indkvarteret i gæsteværelserne, hvor tre mand skulle dele to senge.

I løbet af de følgende dage blev flere og flere dansksindede indsat på Sønderborghus, og gårdejer Peter Grau var en af dem. Han har forklaret, at stedet var blevet indrettet som en feltlejr, hvor fangerne sov i halm og spiste middagsmaden med to skeer, fordi kniv og gaffel var taget fra dem. Soldater fra garnisonen i Sønderborg var fangevogtere, og når de internerede fik besøg af slægtninge, skulle det ske »under en underofficers kontrollerende nærværelse, og samtalen skulle føres på tysk «. ${ }^{88}$

Flere af de arresterede har beskrevet selve arrestationen, og erfaringerne varierer meget betydeligt. Nogle havde oplevet, at de tyske gendarmer havde optrådt brutalt og truet med at skyde, hvis fangerne forsøgte at flygte. Andre havde anderledes fredelige erindringer 
om, hvordan arrestationen fandt sted. Således gik det ganske mærkværdigt til, da gårdejer Nicolai Nielsen blev arresteret: »Jeg ser endnu gendarmen komme kørende herind med arrestanterne Jørgen Berthelsen og Aars Hansen, Tandslet, for at arrestere mig og husker, at han sagde til mig, da vi kørte op til Asserballe, at nu kunne jeg nok køre hen og sige Chr. Ernst Christiansen besked, så ville han imens arrestere Chr. Becker, og da jeg spurgte ham, om det også kunne lade sig gøre, at den ene arrestant arresterede den anden, svarede han »Ach was «.«89

Fangerne i Sønderborg blev overført til kasernen på Sønderborg Slot den 8. august. Især Peter Grau har beskrevet, hvordan det fandt sted. Arrestanterne måtte selv bære deres ejendele, og mange havde samlet ret mange ting sammen, fordi de havde forberedt sig på et længerevarende ophold. De måtte derfor slæbe på både garderobe, sengetøj og andre ting gennem Sønderborgs gader, men »skuet var ikke uden komik, og humøret, hvad der fremgik af replikkerne, heller ikke alt for tragisk «. ${ }^{90}$ Ifølge Skau var gaderne næsten mennesketomme, og der var kun nogle få tysksindede, der hoverede over de interneredes situation.

Selve opholdet på Sønderborg Slot beskrives af arrestanterne som lidt af en feriekoloni. Skau har igen forklaret, at fangerne blev indkvarteret i slottets store rummelige sale, og at 10-40 fanger boede sammen. Maden blev serveret fra kasernekøkkenet, og fangerne havde hver deres seng, der var redt op med halmsække og tæpper. »Her tilbragte en del af os 5 efter omstændighederne meget fornøjelige, men dog noget ensformige uger. Hensigten med vor indespærring? Chikane og økonomisk boykot. Nu kom den længe ventede lejlighed til at komme de fanatiske principaler og deres medhjælpere til livs og stadig øve en gavnlig og nødvendig trussel mod det menige folk. Skulle en sådan lejlighed ikke benyttes? «91 Baggrunden for Graus opfattelse var, at mange af de internerede var gårdejere og selvstændige erhvervsdrivende, og de blev særligt hårdt ramt af interneringen. For gårdejerne var der naturligvis ydermere det problem, at høsten fandt sted, mens de selv sad og kiggede ud ad vinduerne på Sønderborg Slot. Karl Alnor har i sin fremstilling forsøgt at tilbagevise denne opfattelse, at arrestationerne også havde til formål at genere de dansksindede mest muligt - herunder især økonomisk - men tilbagevisningen virker både svag og ubegrundet. ${ }^{92}$

De sidste 46 fanger i Sønderborg blev frigivet lørdag den 12. sep- 
tember 1914. Blandt de sidst frigivne var Peter Skau og redaktør Adolf Svensson. ${ }^{93}$ De to kvindelige fanger - Tilde Svensson fra Kegnæs og frøken Brunthon, der var husbestyrerinde hos landdagsmanden Nis Nissen - blev sat fri allerede den 8. august i forbindelse med flytningen til Sønderborg Slot. ${ }^{94}$ I midten af august blev yderligere 35 mand løsladt, blandt andet de fleste af de internerede fiskere fra Høruphav, Sottrupskov og Broager halvø, og den 7. september blev yderligere syv fanger sat fri. ${ }^{95}$

De fleste arresterede i Aabenraa Amt blev sendt til arresten i Aabenraa, men der er kun meget få beskrivelser af deres forhold. Det hænger utvivlsomt sammen med, at næsten alle arresterede blev løsladt igen umiddelbart efter arrestationen. Af de officielle lister med navnene over de internerede i Aabenraa Amt - som ligger i H.P. Hanssens arkiv - er det skrevet om de internerede fiskere fra Barsø og de politiske fanger fra Aabenraa by: »Interneringssted: Fra begyndelsen i amtsretsfængslet i Aabenraa, efter ordre fra generalkommandoen frigivet den 1. august. « Eller for dem der blev interneret uden for Aabenraa: »Interneringssted: Fra begyndensen anbragt $\mathrm{i}$ amtsretsfængslet, straks frigivet. « ${ }^{96}$ Betydningen af denne lille sprogforskel må være, at det kun var fiskerne og arrestanterne i Aabenraa by, der blev arresteret den 31. juli og løsladt igen den 1. august, mens de øvrige blev arresteret nogle dage senere, men løsladt igen umiddelbart derefter.

Der er dog tre undtagelser fra dette overordnede billede. Den 12. august blev en hr. Askov fra Aabenraa by arresteret og indsat i amtsarresten i byen. Han blev først løsladt igen den 15. august. De to andre - købmand C.C. Biehl og konsulent H. Hansen - boede begge i Gråsten, men blev som de eneste fra Aabenraa Amt fængslet og indsat i Flensborg. ${ }^{97}$ I et privat brev til H.P. Hanssen dateret 4. september 1914 - hvor han fortsat var interneret - skrev Hansen om sine og Biehls oplevelser: »Vi blev arresteret om morgenen den 4. august (tirsdag), sad i arrest i Gråsten, mens amtsforstander med stedfortræder og en reserveunderofficer foretog husundersøgelse hos os. Kl. 2 samme dag blev vi (og pakkerne med materiale fra husundersøgelsen) kørt i bil til Flensborg Kaserne, divisionskommandoen, og til sidst puttet ind i hullerne i politiarresten, hvor vi var, til vi den følgende torsdag blev ført op i det nye gymnasium. Fredag og lørdag (11.8) kom vi i forhør angående materialet." Han forklarede videre, at hans hustru den 21. august havde modtaget et brev dateret 12 . 
august fra statsadvokaten i Flensborg, hvor denne konstaterede, at han ikke havde fundet noget, der berettigede til at indlede en straffesag mod Hansen. Fruerne Hansen og Biehl - der havde fået et tilsvarende brev - mødte derefter op hos divisionskommandoen og regnede med, at de ville få deres mænd med hjem. Men de fik det nedslående svar: "Deres mænd må indtil videre blive her, fordi de er jo danske. $" 98$ Under et nyt forhør i slutningen af august havde Hansen vist brevet fra statsadvokaten, men fået at vide, at brevet ikke betød noget for militæret. Derfor bad han inderligt H.P. Hanssen om at gå videre med sagen, da han var landet midt $i$ en kompetencestrid mellem de civile og militære myndigheder i Flensborg. Først den 9. september 1914 blev de begge løsladt, men det er tvivlsomt, om det direkte skyldes H.P. Hanssens indsats. ${ }^{99}$

De internerede i Haderslev oplevede et meget anderledes forløb end dem fra de øvrige nordslesvigske amter. I bogen Bavnerne brænder fra 1934 udgav journalisten Jes Sarup sin egen og flere andre Haderslev-interneredes beretninger om oplevelserne som preussiske krigsfanger i august 1914. Som nævnt ovenfor blev journalister og redaktører tilknyttet Dannevirke arresteret allerede den 31. juli og indsat i politifængslet i Haderslev. Dagen efter blev otte fiskere fra Aarø samt to fiskere fra Knud Strand og to fra Hejlsminde arresteret og ført til politifængslet i Haderslev. I de følgende dage blev de øvrige arresteret rundt om i amtet, og næsten alle gav i erindringerne udtryk for, at det havde været en meget ubehagelig oplevelse. Gendarmerne, der arresterede fangerne, havde et gevær med, og flere af de arresterede har oplyst, at gendarmerne truede med at skyde, hvis de forsøgte at flygte. Flere har fortalt, at de i første omgang blev indsat i den lokale arrest, inden de blev sendt videre til fængslet i Haderslev, og at opholdet i disse småarrester havde været alt andet end behageligt. Da fangerne var samlet i Haderslev, blev de indsat i eneceller, og alt i alt var det bestemt ikke nogen rar oplevelse.

Det, der gjorde interneringen i Haderslev til noget særligt, var, at 27 fanger lørdag den 8. august 1914 blev sendt af sted til øen Dänholm i havnen ved Stralsund. Blandt dem var der ti fiskere, og 17 politiske fanger, der kom fra hele Haderslev Amt. ${ }^{100}$ Sarup understreger, at det efter en uge i enecelle nærmest var en fornøjelse at være sammen med gode venner på rejsen til Dänholm, og at det var en lise endelig at kunne tale frit sammen igen. Samtidig pointerede han, at de seks landstormsmænd, der sammen med en feldwebel skulle bevogte 
fangerne, "alle sammen var kendte nordslesvigere, og for de fems vedkommende gode danske mænd «. ${ }^{101}$ Det er især Sarup, Svendsen og Callø, der grundigt har beskrevet turen til og opholdet på Dänholm. ${ }^{102}$ Turen derned var ualmindelig langsommelig, og fangerne nåede først frem den 12. august. Turen beskrives af alle tre som fredsommelig og hyggelig, men naturligvis også præget af stor uvished med hensyn til fremtiden. Callø har udtrykt dette meget præcist: »Over de lyse og muntre episoder, som erindringer med forkærlighed dvæler ved nu, da der er fred og ingen fare, må man ikke glemme den mørke baggrund. Vi svævede bestandig i pinlig uvished om vor skæbne, og det skortede ikke på ubehagelige oplevelser.«103

De danske fanger blev indkvarteret sammen på øen, der tidligere havde været en preussisk kaserne. Ifølge Sarup var der indsat 600 krigsfanger fra forskellige lande. ${ }^{104}$ Beretningerne bærer præg af, at hverken de ledende officerer eller de internerede danskere vidste, hvorfor de var blevet sendt til øen, eller hvad der skulle ske med dem fremover. Det illustreres af, at den ledende major den 19. august havde besøgt danskerne, og ifølge Sarups udlægning havde han oplyst, "at vor sag lå hos Krigsministeriet i Berlin. Majoren vidste ikke, hvad han skulle stille op med os, da øen Dänholm i grunden kun var forbeholdt krigsfanger. Han havde sendt forespørgsel både til generalkommandoen i Altona og til militærmyndighederne i Haderslev, der jo havde foretaget arrestationen, om hvad han skulle gøre med os. De havde ikke givet ham nogen besked. «105

Samme dag - den 19. august - fik danskerne besked om, at de skulle rejse igen, men der var ingen oplysninger om, hvor de skulle hen. Rygtet gik snart, at de ville blive sendt hjem til Haderslev, og derfor var skuffelsen stor, da de i stedet havnede i Altona. Det er igen Sarup, Svendsen og Callø, der har beskrevet opholdet i Altona, og de skriver samstemmende, at fangerne blev godt modtaget. Maden var god og rigelig; fangerne blev godt indkvarteret, og de blev retfærdigt behandlet af to overkrigsretsråder og en krigsretsråd. ${ }^{106}$ Afhøringerne blev foretaget den 20. august, og det tog lang tid, da der var 27, der skulle afhøres. Men »i ventetiden kom en af skriverne ind til os og fortalte, at vi formodentlig ville blive anbragte i et par mandskabsstuer på kasernen. Men det ville sikkert kun dreje sig om et par dage, før hjemrejsen kunne ske. Det var toner, som vi kunne lide at høre «. ${ }^{107}$

Dagen efter blev de første fanger frigivet, idet syv fiskere og den alderdomssvækkede redaktør Matthiesen blev løsladt og sendt til 
Haderslev natten til den 22. august. Dagen efter blev endnu én - Axel Sabroe - sendt hjem, men det var først den 29. august, at de sidste fanger blev frigivet. ${ }^{108}$ Den 30. august sendte P.A. Callø et telegram til Hanssen, hvor han helt kort skrev, at alle fanger nu var frigivet: »Vi har oplevet forskelligt, men bortset fra usikkerheden har vi egentlig ikke noget at klage over. «109 Hanssen var i Berlin på dette tidspunkt, men han blev alligevel underrettet om Calløs meddelelse, hvilket fik betydning for hans drøftelser under sit ophold i Berlin frem til den 2. september. ${ }^{110}$

I Tønder var historien om de internerede dansksindede igen helt anderledes, og den er i virkeligheden delt i to. De første arrestationer fandt sted den 1.-2. august 1914, og fangerne blev umiddelbart derefter sendt til generalkommandoen i Altona. Efter et kort ophold her, blev fangerne sendt retur til Tønder. Den anden runde arrestationer fandt sted fra omkring den 3.-4. august og den følgende uge, og fangerne blev kort efter sendt til Flensborg, hvor de fleste sad helt frem til midten af september 1914.

Det er især P. Skovrøy og Thorvald Petersen, der har berettet om de første arrestationer og om turen til Altona. ${ }^{111}$ Skovrøy har fortalt, at han blev vækket ved to-tiden om morgenen den 2. august, ved at to politibetjente stod foran hans seng og meddelte, at han skulle i "Schutzhaft «. ${ }^{112}$ Samtidig blev hans husholder Christine Outzen taget med, og de blev ført til »fængslet på Slotsbanken, i hvis usle huller vi tilbragte natten sammen med andre fra Tønder by, bankdirektørerne Rossen og Andresen samt bagermester Thorvald Petersen, for næste dag at samles med 37 fra omegnen ${ }^{113}$

Midt på eftermiddagen den 2. august blev fangerne samlet, og de gjorde klar til at gå ned på stationen. På denne tur truede soldaternes med at skyde, hvis nogen trådte ud af rækken eller forsøgte at flygte. Turen gennem Tønders gader beskrives som hæslig, idet den med Skovrøys ord foregik »under den grove og den fine tyske pøbels forhånelser, sang, skrig og skrål af børn og voksne mennesker, som fulgte os eller stod opstillede langs fortovene, i vinduer og døre; de hylede skældsord efter os, truede med knyttede næver, spyttede eller rakte tunge ad os «. ${ }^{114}$ Petersens beretning om turen minder meget om Skovrøys, og også han fremhæver det ubehagelige i, at borgere, der ellers ikke tidligere havde udtrykt danskfjendtlige holdninger, pludselig deltog i den hadefulde forhånelse af de dansksindede fanger. ${ }^{115}$ Beskrivelserne af, hvordan fangerne blev behandlet af borgerne i Tøn- 
der under gåturen gennem byens gader, er således helt anderledes end beskrivelserne af, hvordan borgerne i Sønderborg opførte sig, da fangerne der blev flyttet fra Sønderborghus til Sønderborg Slot. Det kan dog muligvis også hænge sammen med, at gåturen i Tønder fandt sted den 2. august, mens turen gennem Sønderborg først skete den 8. august, hvor den første krigsrus havde lagt sig.

Der var 42 mennesker fra Tønder Amt, der blev sendt til Altona, hvor de ankom tidligt om morgenen den 3. august. De gik til politifængslet i Katharinenstrasse, og Petersen har beskrevet det som et sørgeligt syn: "syge kvinder, gamle mænd (Skovrøy havde lige overstået en operation), bønderkoner, bankdirektører, landmænd, håndværkere, unge karle og piger. «116 Han har også forklaret at politifolkene, der fulgte fangerne gennem byen, havde små dannebrogsflag på ærmet som et symbol på, at de kunne tale dansk. Det forklarede Petersen med, at »her havde man øjensynligt det ind tryk, at det var kongerigske danske, man havde med at gøre, og at vi var blevet nappet som spioner eller lignende «. ${ }^{117}$

Selve forhørene beskrives som noget af en farce. Skovrøy forklarede kort, at en fornuftig dommer om eftermiddagen den 3. august satte fangerne på fri fod, hvorefter de kunne rejse tilbage til Tønder. ${ }^{118}$ Petersen var noget mere kritisk, idet han anførte, at arrestationerne og turen til Altona slet ikke hang sammen. Ingen i Altona vidste, hvorfor danskerne var arresteret, og hvorfor de var sendt derned. En efter en blev fangerne kaldt ind til forhør, »men da man var færdig med den syvende, lød der pludselig en skrålen ude på gangen - dørene blev slået op med et: 'Fertig machen, nach Hause «. Dommeren fandt åbenbart ingen grund til at afhøre flere og må have ment, at der ikke var noget grundlag for at opretholde arrestationen af fangerne, hvorfor han valgte at slippe dem fri. For at gøre turen til Altona endnu mere absurd, måtte fangerne selv betale for at få bragt middagsmad fra en nærliggende restaurant, ligesom de selv måtte betale togbilletterne tilbage til Tønder. ${ }^{119}$

Umiddelbart efter fangerne fra Tønder var blevet sendt til Altona den 2. august gik de lokale myndigheder i gang med at arrestere flere dansksindede, som blev indsat i fængslet i Tønder. Tre af de første var købmand Lorens Filskov, gårdejer Thomas Thomsen og godsinspektør H.C. Davidsen, der alle blev arresteret om morgenen den 3. august. ${ }^{120}$ I de følgende dage blev flere arresteret og indsat $i$ arresten i Tønder, indtil de den 7. august blev sendt til Flensborg. Lorens Filskov lod sin bagage blive tilbage i Tønder, fordi han blev fortalt, at de efter en afhøring i Flensborg ville blive frigivet. Sådan gik det ikke, 


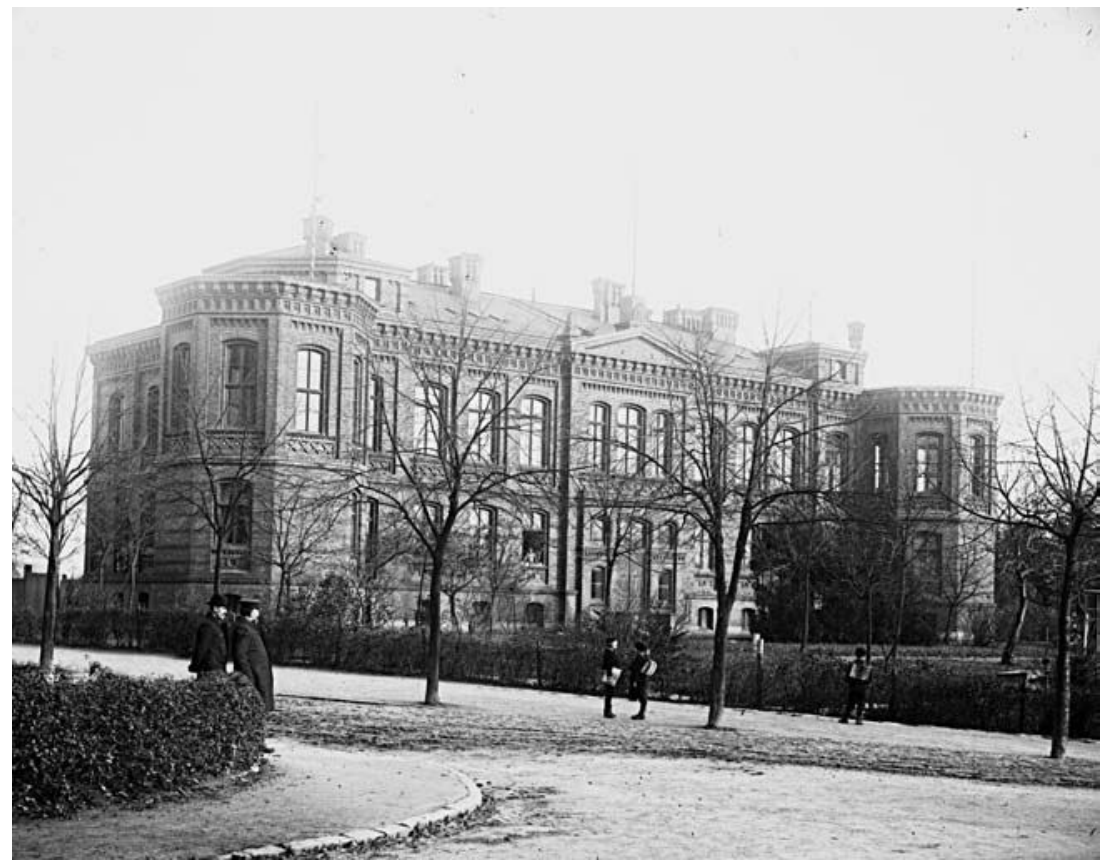

Billede fra omkring 1920 af den kongelige navigationsskole, Munktoft 3 i Flensborg. Fotograf: Remmer. Mere end 40 arresterede fra Flensborg By og Tønder Amt blev først interneret på det gamle gymnasium i Flensborg og siden på Navigationsskolen $i$ byen. Foto: Arkivet ved Dansk Centralbibliotek for Sydslesvig.

og han har forklaret det med, at »den fungerende politimand lod os forstå, at vor eventuelle frigivelse afhang af, om Danmark holdt sig neutral (gidsel) «. ${ }^{121}$ Han er den eneste, der har forklaret interneringerne med, at de fungerede som gidsler for at holde Danmark uden for krigen, og begrundelsen forekommer tvivlsom. I hvert fald er det ikke noget, som H.P. Hanssen har antydet i sin dagbog.

Kun en uges tid efter, at de frigivne Tønder-fanger var kommet tilbage fra Altona, blev 15 af dem arresteret igen. Thorvald Petersen, Rasmus Rossen, Andreas Andresen og Peder Skovrøy blev igen hentet til arresten i Tønder, inden også de blev sendt til Flensborg. Det samme blev nogle »nye « fanger fra Tønder-området. De blev alle interneret på det gamle gymnasium i Flensborg, hvor Tønder-folkene kom til at sidde sammen med de øvrige internerede fra Tønder og dem fra Flensborg. ${ }^{122}$

Det er ikke fuldstændig klart, hvor mange der var interneret på det 
gamle gymnasium i Flensborg - og fra den 24. august på Navigationsskolen i Munketoft. H.C. Davidsen tegnede portrætter af de internerede, og han har i alt tegnet 36 mennesker, hvilket i hvert fald betyder, at der mindst var 37 med ham selv. I slagter Sørensens beretning er der afskrevet to numre af de indsattes avis, Flensborg Arrestavis, og ifølge udgaven fra den 15. august var der listet 43 navne op, og det forekommer sandsynligt at det er en korrekt opgørelse. ${ }^{123}$ Dog har Tycho Filskov anslået, at der i alt var omkring 60 fanger. ${ }^{124}$ Af dem var hele redaktionen på Flensborg Avis - E. Christiansen, P. Simonsen, L.P. Christensen og Tycho Filskov samt bogholder Jørgen Vrang - interneret, ligesom Andreas Grau og fire farvandskyndige kaptajner fra Flensborg var blandt fangerne. ${ }^{125}$ På et værelse boede de tre arresterede kvinder, fru M. Sørensen, Ballum, fru Berthelsen, Ballum, og fru A. Jessen fra Tinglev. ${ }^{126}$ Det vides dog også, at Hansigne Lorenzen fra Ballum var blandt de internerede, men hun blev indkvarteret sammen med sin mand, Hans Lorenzen. ${ }^{127}$

Der er skrevet flere beretninger om opholdet først på det gamle gymnasium og siden på Navigationsskolen i Flensborg, men det er især O.D. Schacks beskrivelse, der benyttes her. ${ }^{128}$ Det skyldes, at Schacks historie er noget anderledes end de øvrige interneredes, dels fordi han var arresteret i næsten fire måneder og dels fordi myndighederne forsøgte at få ham dømt som landsforræder. Alle de internerede beskriver forholdene som forholdsvis gode og afslappede, og det mindede meget om de forhold, der herskede på Sønderborg Slot. I den indledende fase var der restriktioner på, hvor meget fangerne kunne omgås hinanden, men især efter flytningen til Navigationsskolen kunne de stort set uhindret bevæge sig rundt og tale med hinanden, som de ville. Tycho Filskov har forklaret, at Flensborgs overborgmester Todsen besøgte fangerne den 24. august, kort efter flytningen, for at se, hvordan de var blevet installeret. »Vi udtalte vores påskyndelse af den skete forbedring « og fremsatte flere ønsker, som Todsen lovede at se, om han kunne opfylde, men »det var jo militæret, der havde det afgørende ord «. Et af ønskerne - som blev gennemført - var, at fangerne derefter kunne få bragt mad hjemmefra eller fra en nærliggende restaurant, hvis de selv betalte for maden. ${ }^{129}$

Schack blev arresteret den 7. august 1914, og samtidig blev der foretaget en omfattende ransagning af hans private kontor og af Landeværnets kontor i portnerbygningen ved Schackenborg. ${ }^{130}$ Schack var sekretær og kasserer i Landeværnet, der var en forening, som var 
startet i 1913 med det formål at forhindre, at gårde i Sønderjylland blev omdannet til såkaldte "rentegårde«, hvor den tyske stat ydede billige lån, mod at der var knyttet en statslig genkøbsret. Det stod tilsyneladende hurtigt klart, at der ikke i Schacks private papirer var materiale til en spionanklage, men at der i Landeværnets arkiv dels var kartoteker over medlemmerne af foreningen og dels manuskripter af de taler, han havde holdt rundt om i Nordslesvig og i Danmark om betydningen af Landeværnet i forhold til den såkaldte »bindelov«. Og det var især talerne, der udgjorde kernen i den sag, som myndighederne forsøgte at stable på benene.

I modsætning til de andre internerede blev Schack høfligt bedt om at stille på landråd Böhmes kontor den 6. august, hvor han måtte underskrive en advarsel. Han blev altså alligevel arresteret dagen efter og i bil fragtet til Flensborg. Under forhøret blev han betegnet som "sandsynlig spionmistænkt«, hvilket han opponerede stærkt imod men uden effekt. ${ }^{131}$

Landråd Böhme sendte to breve den 6. august 1914, et til generalkommandoen og et til overpræsidenten. I begge forklarede han, at han havde haft mødet med Schack, og at han havde advaret greven mod at foretage sig noget tyskfjendtligt eller lignende. Han forklarede også, at det ville blive svært at sikre, at Schack undlod at foretage sig noget suspekt, hvis ikke greven blev interneret. I brevet til overpræsidenten betonede han dog, at »jeg af politisk-taktiske grunde har betænkeligheder ved at skride til anholdelse, da han har prominente slægtninge i Danmark, og der ved en agitation til fordel for ham muligvis vil kunne betyde en afståelse af Danmarks neutralitet «. ${ }^{132}$ Alligevel anbefalede Böhme, at Schack blev interneret, hvilket altså skete dagen efter.

Schack blev indsat i sit eget klasselokale, men da Skovrøy blev arresteret igen, blev han flyttet ind til Schack. De har begge givet udtryk for, at det var til gensidig fornøjelse. Et par dage forud for flytningen til Navigationsskolen gik rygtet blandt fangerne, at de skulle flytte muligvis til Dänholm. Derfor tilbød Schack, at Schackenborg i stedet kunne bruges som arrestlokale for fangerne på Sønderborg Slot og dem fra det gamle gymnasium i Flensborg, hvis der var pladsmangel, men det var altså et tilbud, myndighederne undlod at benytte. ${ }^{133}$

Schack holdt helt tydeligt af det samvær og sammenhold, der var mellem de internerede. Både at der blev dyrket gymnastik, at der blev spillet kort og skak, at der blev drukket cognac og røget cigarer, at 
der blev udgivet en fornøjelig Flensborg Arresttidende, og at fangerne kunne tale nogenlunde frit sammen. Det er måske lidt af en efterrationalisering, når han konstaterer: "Set fra et dansk nationalt synspunkt var interneringerne i Sønderjylland et enestående held. Da krigen brød ud, var vi klar over, at vort nationale arbejde måtte standse. [...] På gymnasiet i Flensborg blev vi igen de samme sønderjyder, der var stævnet til årsmødet i Haderslev få uger i forvejen, og det blev vi ved med at være, også efter at vi var kommet på fri fod igen.«134 Sagt på moderne dansk fik interneringerne altså danskerne til at rykke tættere sammen i bussen. Ikke blot dem der var lukket inde i nogle uger, men også alle andre dansksindede nordslesvigere.

I løbet af september 1914 blev de øvrige fanger i Flensborg løbende løsladt. Først blev de farvandskyndige frigivet lige i starten af måneden, mens redaktionen på Flensborg Avis slap ud den 5. september dog med undtagelse af Tycho Filskov, der nægtede at underskrive den erklæring, som myndighederne forlangte underskrevet ved frigivelsen. Biehl og Hansen fra Gråsten blev løsladt den 9. september, mens 19 af fangerne fra Tønder blev frigivet den 13. september. Den 21. september blev yderligere fire frigivet - heriblandt Skovrøy - og der var derefter kun fire tilbage. To af de øvrige blev frigivet de følgende dage, mens Tycho Filskov først blev frigivet den 8. oktober 1914, hvorefter Schack sad alene tilbage. Grunden til, at Filskov nægtede at underskrive erklæringen, var, at han ønskede at sidde arresteret længst muligt, da han i forbindelse med frigivelsen ville blive indkaldt som soldat. Derfor var han i egen interesse interneret i mere end to måneder. ${ }^{135}$

Schack har betegnet de næste par uger som de værste i den tid, han var interneret, fordi der ingen medfanger var tilbage. Ganske vist fik han mange besøg, ligesom han havde et godt forhold til vagtpersonalet, men han sad alligevel selv tilbage på Navigationsskolen. Perioden som eneste fange sluttede den 30. oktober, da Andreas Grau og dennes hustru blev sat fast igen, fordi de havde besøgt Graus forældre på Als og »rejst omkring til forskellige bekendte«, uden at han havde indhentet myndighedernes tilladelse i forvejen. ${ }^{136}$

Selve sagen mod grev Schack er interessant, fordi myndighederne forsøgte at opbygge en spionage-anklage imod ham. Første gang han hørte, at dokumenterne, der blev beslaglagt i forbindelse med ransagningen, var blevet sendt til Rigsretten i Leipzig, var den 21. september. Selv derefter var det uklart for ham, hvad han nærmere var 


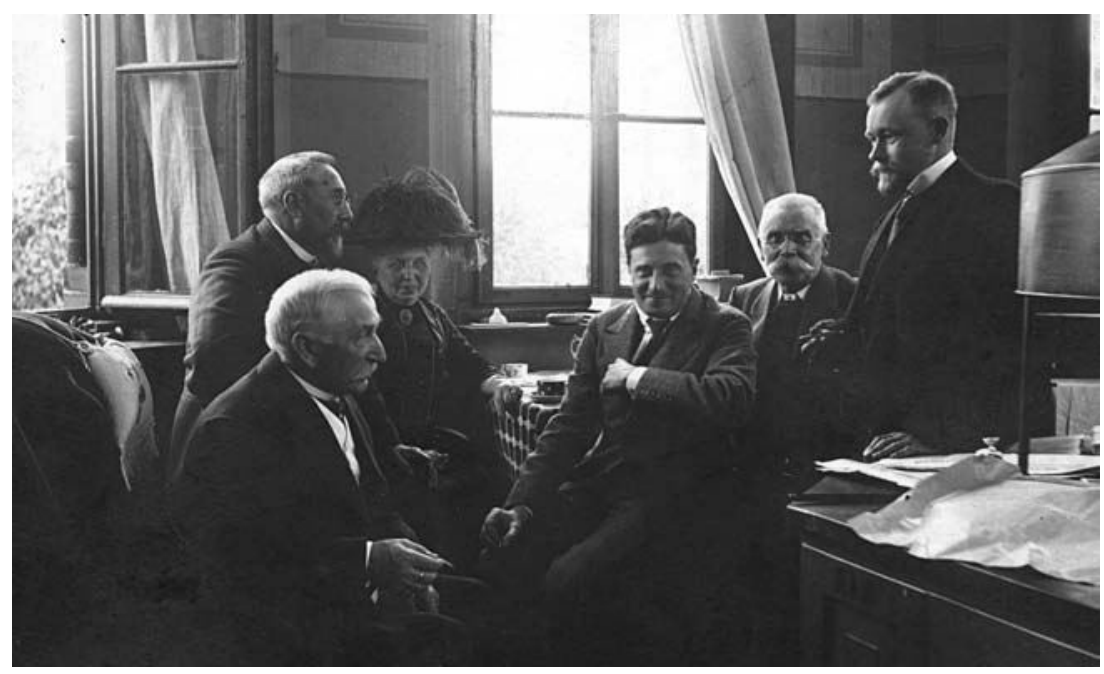

Fotografi af seks internerede på Navigationsskolen i Flensborg. Fra venstre til højre er det bankdirektør Rossen, Lorens Paulsen og hustru, grev Schack, Skovrøy og godsinspektør Davidsen. Grev O.D. Schack var den, der kom til at sidde længst tid interneret. Som det fremgår af billedet, var interneringen også kendetegnet ved hygge og samvær med andre dansksindede. Hvis Schack var blevet dømt for landsforræderi, risikerede han at blive henrettet. Fotograf: Oscar Poulsen. Foto: Arkivet ved Dansk Centralbibliotek for Sydslesvig.

anklaget for, og hvad han risikerede, hvis han blev dømt skyldig. H.P. Hanssen var meget aktivt involveret i Schacks sag, og i et brev dateret 24. oktober skrev han, at indenrigsminister von Loebell havde bekræftet, at der var indledt en undersøgelse imod Schack for højeller landsforræderi, og at sagen i sidste ende kunne føre til henrettelse. ${ }^{137}$ Det fik Schack til at hyre en advokat, der den 6. november rettede henvendelse til den overrigsanklager i Leipzig, der arbejdede med sagen. Allerede tre dage senere skrev denne tilbage: »Under henvisning til Deres forespørgsel af 6. denne måned kan jeg hermed oplyse, at jeg har indstillet processen mod grev Schack af Schackenborg og har meddelt dette til den stedfortrædende generalkommando for 9 . Armekorps. «138 Dermed skulle sagen være afsluttet, og Schack klar til frifindelse, men sådan gik det ikke. I hvert fald sad han arresteret helt frem til den 2. december, hvor han endelig blev sat fri.

Indenrigsministeren gik ind i sagen mod Schack den 1. oktober 1914, hvor han skrev et brev til overpræsidenten. ${ }^{139}$ Heri forklarede han, at han ikke var et øjeblik i tvivl om, at Schacks hovedmål var 
Nordslesvigs løsrivelse fra Tyskland og landsdelens genforening med Danmark, men at det ikke ville række til at få ham dømt for landsforræderi. Han gik skridtet videre og forklarede, at Vælgerforeningen, Sprogforeningen og Skoleforeningen gennem 20 år »havde udgjort rygraden i den danske agitation i Nordslesvig «, men at disse foreninger ligesom Landeværnet var beskyttet af den »Reichsvereinsgesetz« rigsforeningslov - der var blevet vedtaget den 19. april 1908. Allerede den 6. oktober 1914 meddelte overrigsanklageren i et brev til generalkommandoen, at han helt i tråd med indenrigsministerens begrundelser droppede sagen. Herefter gik der næsten to måneder, hvor den kommanderende general von Roehl fortsat ønskede at have Schack interneret, og hvor han som minimum krævede, at greven skulle underskrive en loyalitetserklæring, inden han kunne frigives. Det var først, da generalen til sidst gav sig på dette punkt, at Schack slap ud.

En del af problemstillingen var, at Schack nægtede at underskrive den erklæring, som alle andre dansksindede havde været tvunget til at underskrive, selv om indenrigsministeren allerede i slutningen af august beordrede landråderne til at undlade at kræve disse erklæringer. Erklæringen var stort set ens i alle amterne, og den bestod af fem punkter: 1) at de ikke måtte udvise »ikke-tysk sindelag «, 2) at de ikke ville understøtte, begunstige eller understøtte noget, der var i modstrid med tyske interesser, 3) at de ikke ville udbrede nyheder af militær eller politisk interesse, især ikke i udlandet, 4) at de ikke ville deltage i danske foreninger eller forsamlinger, og 5) at de ikke ville forlade hjemkommunen, uden at politimyndighederne $i$ forvejen havde godkendt det. ${ }^{140}$ I Tønder var der yderligere tilføjelser og en besked om, at de dansksindede i tilfælde af overtrædelser ville blive arresteret på ny. ${ }^{141}$ Egentlig var ingen af punkterne spiselige for danskerne, men der var enighed om, at det sidste punkt var det mest problematiske, fordi det nærmede sig en slags husarrest. Men reglen blev aldrig håndhævet hårdt, og Andreas Graus arrestation - der er nævnt ovenfor - er det eneste kendte eksempel på, at der var nogen dansksindede, der blev arresteret for at overtræde forbuddet og indsat i længere tid.

\section{Sammenfatning}

Med grev Schacks løsladelse i begyndelsen af december 1914 var alle de dansksindede, der blev interneret ved krigens udbrud, igen på fri 


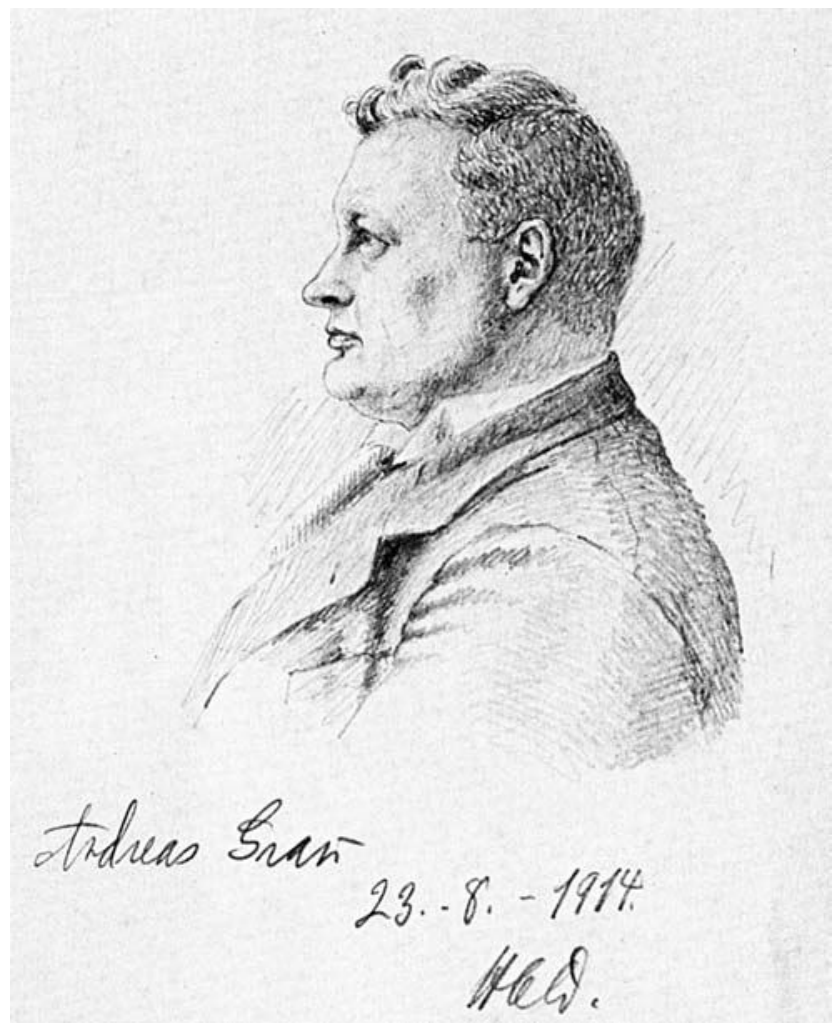

Tegning af Andreas Grau lavet af H.C. Davidsen i august 1914 under interneringen i Flensborg. Journalisten Andreas Grau blev regnet som en farlig »Jungdänenführer «. Han blev arresteret anden gang $i$ slutningen af oktober 1914, mistænkt for at have indsamlet oplysninger på Als og sendt dem til Danmark via sin hustru.

fod. De fleste blev løsladt efter nogle få uger, og fangerne blev generelt behandlet udmærket. Efter frigivelserne og åbningen af de danske aviser nærmede forholdene i Nordslesvig sig det normale. Men der var fortsat streng censur, og de danske slesvigere var fortsat under skrap kontrol med risiko for arrestation og fængselsstraf. De danske aviser blev under krigen flere gange lukket i kortere perioder, men ellers herskede der nogenlunde ro i Nordslesvig, og undertrykkelsen af de dansksindede var mindre udtalt.

Arrestationerne og avislukningerne har siden tiltrukket sig beskeden opmærksomhed, hvilket utvivlsomt mest skyldes, at det var af langt større betydning, at omkring 30.000 unge dansksindede mænd 
blev indkaldt som tyske soldater, og at 5.-6.000 af dem faldt i krigen. Det ændrer dog ikke ved, at myndighedernes undertrykkelse af de dansksindede i krigens indledende fase blev opfattet som et voldsomt og ubegrundet overgreb.

Forløbet kan ikke alene forklares med, at de militære myndigheder overtog magten i Nordslesvig, og at generalkommandoen i Altona dikterede, hvad der skulle ske. De lokale landråder og amtsforstandere havde den afgørende indflydelse på, hvem og hvor mange der blev arresteret, ligesom de dikterede, hvor længe fangerne sad i fangenskab. I Sønderborg Amt greb det i den grad om sig - både hvad angår antallet af arresterede og med hensyn til længden af interneringerne mens arrestationerne i Tønder virkede kaotiske og ugennemtænkte. I Haderslev blev der interneret relativt få, men de blev til gengæld sendt ud på en lang rejse til Dänholm og Altona, inden de blev frigivet. I Aabenraa blev der ganske vist interneret ret mange mennesker, men de blev til gengæld næsten alle frigivet umiddelbart efter arrestationen. Flensborg var det sted, hvor der blev arresteret langt færrest, og tilsyneladende var byens overborgmester interesseret $i$, at forholdene for de internerede var så gode som muligt.

Samlet er forløbet ganske kaotisk. De centrale myndigheder i Berlin - det vil sige ledelsen af Udenrigsministeriet og Indenrigsministeriet - vidste tilsyneladende ikke, hvad der skete i Nordslesvig. Og da de gennem H.P. Hanssen fik det at vide, gik der forholdsvis lang tid, inden der blev gjort noget ved det. De lokale civile og militære myndigheder fulgte en anden og langt hårdere linje over for de dansksindede slesvigere, end det der var ønsket af regeringen. Uanset at indenrigsminister von Loebell gentagne gange instruerede overpræsidenten i Slesvig om, at de præventive arrestationer og avislukninger i Nordslesvig var imod regeringens ønsker, fik de fleste internerede lov til at sidde indespærret i flere uger, efter at regeringen fik kendskab til sagen. Derfor forekommer det meget sandsynligt, at H.P. Hanssens vedvarende indsats for at få frigivet danskerne fik en stor betydning for, at det efterhånden skete.

\section{KILDER OG LITTERATUR}

Kilder:

Landesarchiv Schleswig-Holstein (LSH):

Oberpräsidium und Provinzialrat der
Provinz Schleswig-Holstein, Bestandes Abt. 301:

1670: Dänische Presse in Nordschleswig. 
1714: Dänische Agitation des Lehnsgrafen Otto Schack-Schackenburg.

1715: Agitation des Jungdänenführers Andreas Grau, Flensburg.

1718: Entfernung politisch unzuverlässiger, fahrwasserkundiger Personen, die vom Feind zum Lotsendienst herausgezogen werden können.

1719: Entfernung politisch unzuverlässiger, fahrwasserkundiger Personen, die vom Feind zum Lotsendienst herausgezogen werden können, Allgemeines.

1707-1712: Festnahme von Personen beim Eintritt innerer Unruhen und bei Kriegsgefahr. Allgemeines + Bd. 1-5.

1720: Listen über politisch unzuverlässige, fahrwasserkundige Personen, die im Kriegsfall zu entfernen sind.

Landsarkivet i Aabenraa (LAA):

RA0664: Otto Didrik Schack: Acc. 168912: 1914-1914: Interneringstiden.

RA0664: Otto Didrik Schack: Acc. 168913: 1914-1914: Interneringstiden.

sbac335: Foreningen »Danske Civilfanger 1914 .

RA0272: Hans Peter Hanssen, Rigsdagsmand: 272/-112: 1914-1920: Dagbøger.

RA0272: Hans Peter Hanssen, Rigsdagsmand: 272/-112: 1914-1920: Optegnelser i afsk. gg aktstykker vedr. jun-jul 1914 og 1918-1920.

RA0272: Hans Peter Hanssen, Rigsdagsmand: 272/-116a: 1914-1920: Optegnelser i afsk. og aktstykker vedr. jun-jul 1914 og 1918-1920.

RA0272: Hans Peter Hanssen, Rigsdagsmand: 272/139.

RA0272: Hans Peter Hanssen, Rigsdagsmand: 272/145.

RA0272: Hans Peter Hanssen, Rigsdagsmand: 272/196.

RA0272: Hans Peter Hanssen, Rigsdagsmand: 272/199.

\section{Litteratur:}

Alnor, Karl: Handbuch zur schleswigschen Frage. Band II: Die schleswigsche Frage und der Weltkrieg, Neumünster 1927.

Berthelsen, Th. (udg.): Under prøjsisk
Arrestation. Danske Civilfanger 1914. Sønderborg 1939.

Beyer, Hans: „Überfremdung der schleswig-holsteinischen Verwaltung? E. Böhme und Fr. Knutzen - zwei hervorragende Landräte aus Angeln «, Jahrbuch des Angler Heimatsvereins. 34. Jahrgang 1970, s. 34-43.

Bonefeld, Olav: "Civilfanger i 1914", Skrift for Historisk Forening for Sundeved 1995, s. 74-98.

Clemmensen, Michael H.: »H.P. Hanssen - den danske generalstabs stjerneagent ' $Z$ ' i Berlin ", Sønderjysk Månedsskrift 2012:3, s. 114-121.

la Cour, Vilhelm: Sønderjylland under Verdenskrigen August 1914-1916, København 1916.

Danker, Uwe og Jørgen Kühl (red.): Quellen zur Geschichte der deutsch-dänischen Grenzregion. Kilder til den dansktyske grænseregions historie. IV. Der nationale Gegensatz. De nationale modsxtninger. 1914-1933, Aabenraa/Flensburg 2001.

Davidsen, H.C.: Forbryderalbum, Tønder 1973.

Dybbøl-Posten: Da den store Verdenskrig antændtes. Minder fra Avgustdagene 1914. Sxrtryk af »Dybbøl-Posten «, Sønderborg 1924.

Filskov, Lorens: "Statsfange i Flensborg 1914«, Sønderjyske Årbøger 1993, s. 109124.

Filskov, Tycho: Seks Aar for Rachel, Tønder u.å.

Hanssen, H.P.: Fra Krigstiden 1-2, København 1924.

Harrebye, Jens: »Freiherr von Löw den sidste tyske landråd i Haderslev«, Langs fjord og dam. Lokalhistorie omkring Haderslev 2006, s. 20-24.

Jørgensen, H.P.: »Fangerne på Flensborg Gymnasium August 1914" ", Sønderjysk Månedsskrift 1946, s. 72-80.

Nielsen, Kirsten Grau: Andreas Grau og Sønderjylland. Midt $i$ striden. 19061935, Viborg 2005.

Petersen, Thorvald: Fra Als til Tønder, Tønder 1952.

Rasmussen, René: »Interneringen af de danske ledere og farvandskyndige i 1914«, Adriansen, Inge og Hans Schultz Hansen (red.): Sønderjyderne 
og den store krig 1914-1918, Aabenraa 2006, s. 77-94.

Sarup, Jes: Bavnerne brænder, København 1934.

Schack, O.D.: Grænsesind. Optegnelser fra årene 1913-49, Tønder 1970.

\section{NOTER}

1. I denne artikel bruges udtrykkene "arrestation « og »internering « synonymt.

2. Alnor 1927, s. 663-705.

3. Det illustreres blandt andet af, at overskriften på et af kapitlerne er »Der Landesverrat H.P. Hanssens «.

4. Rasmussen 2006.

5. Hanssen 1924 og Schack 1970.

6. De fleste af dagbøgerne opbevares på Landsarkivet for Sønderjylland; RA0272/112: Hans Peter Hanssen, Rigsdagsmand: 1914-1920: Dagbøger.

7. Dette afsnit er især baseret på Alnor 1927, s. 663-664.

8. Hanssen 1924, s. 282-284.

9. Hanssen 1924, s. 283.

10. Landrat'en var den øverste civile myndighed i et amt. I Nordslesvig var der frem til 1920 fire amter, nemlig Tønder, Haderslev, Aabenraa og Sønderborg. I Flensborg by var det overborgmester Todsen, der fungerede som en slags landråd.

11. Amtsvorsteher'en var en embedsmand, der nogenlunde svarer til danske amtmænd. De havde en række civile opgaver med hensyn til blandt andet sikkerhed, sundhed og sindelag.

12. Alnor 1927, s. 663-664.

13. En Gemeindevorsteher svarer nøje til de danske sognerådsformænd.

14. Dette afsnit: LSH: Bestandes Abt. 301, 1718-1720 samt 1707-1711.

15. LSH: Bestandes Abt. 301, 1718.

16. LSH: Bestandes Abt. 301, særligt 1708 og 1709.

17. LAÅ: RA0272/116a: Hans Peter Hanssen, Rigsdagsmand: 1914-1920: Optegnelser i afsk. og aktstykker vedr. jun-jul 1914 og 1918-1920.

18. Alnor 1927, s. 665.

19. Ibid.
Svendsen, Nicolai: Sønderjysk Skæbne 12, Haderslev 1953.

Svensson, A: De stille Aar, Dy-Po Bogforlag 1962.

20. Alnor 1927, s. 665-666.

21. LSH: Bestandes Abt. 301, 1708.

22. LAÅ: RA RA0272/116a: Hans Peter Hanssen, Rigsdagsmand: 1914-1920: Optegnelser i afsk. og aktstykker vedr. jun-jul 1914 og 1918-1920.

23. Alnor 1927, s. 698.

24. Ibid.

25. Alnor 1927, s. 672-674.

26. Alnor 1927, s. 698.

27. LAÄ; RA0272: Hans Peter Hanssen, Rigsdagsmand: 272/-112: 1914-1920: Optegnelser i afsk. og aktstykker vedr. jun-jul 1914 og 1918-1920.

28. LAÅ: Foreningen »Danske Civilfanger 1914 ".

29. Alnor 1927, s. 820.

30. LSH: Bestandes Abt. 301, 1715.

31. Rasmussen 2006 og www.vimu.info, 15.7.2014.

32. Alnor 1927, s. 701.

33. Rasmussen 2006, s. 80-81, og Berthelsen 1939, s. 15.

34. LAÅ: RA0272/116a: Hans Peter Hanssen, Rigsdagsmand: 1914-1920: Optegnelser i afsk. og aktstykker vedr. jun-jul 1914 og 1918-1920.

35. Ibid.

36. Dybbøl-Posten 1924, s. 28.

37. Bayer 1970, s. 34.

38. Schack 1970, s. 56.

39. Pedersen 1952, s. 109.

40. LAA: RA0272/116a: Hans Peter Hanssen, Rigsdagsmand: 1914-1920: Optegnelser i afsk. og aktstykker vedr. jun-jul 1914 og 1918-1920.

41. Alnor 1927, s. 820.

42. Alnor 1927, s. 673.

43. LSH: Bestandes Abt. 301, 1708.

44. Harrebye 2006, s. 21.

45. Alnor 1927, s. 677.

46. Sarup 1934, s. 124-133, og Svendsen 1953, s. 305-306.

47. Sarup 1934, s. $134-136$, s. $10-13$ og s. 137-140. 
48. Sarup 1934, s. 79-82, og Svendsen 1953, s. 298-301.

49. Berthelsen, udg. 1939, s. 26-30.

50. Ibid.

51. Berthelsen udg. 1939 , s. 30-34, og Hanssen 1924, s. 35-37.

52. LAÅ: RA0272/139: Hans Peter Hanssen, Rigsdagsmand.

53. Berthelsen udg. 1939, s. 33.

54. Hanssen 1924, s. 35-36.

55. Ibid.

56. Ibid.

57. Flensborg Avis, 28/8-1914.

58. Ibid.

59. Hanssen 1924, s. 36-37.

60. LAÅ: RA0272/139: Hans Peter Hanssen, Rigsdagsmand. Brev dateret 27/8-1914 fra »Landratsamt Apenrade« til H.P. Hanssen.

61. Berthelsen udg. 1939, s. 26.

62. Hanssen 1924, s. 7-103.

63. Hanssen 1924, s. 16-17.

64. LAÅ: RA0272/139: Hans Peter Hanssen, Rigsdagsmand.

65. LAÅ: RA0664: Otto Didrik Schack: Acc. 1689-12: 1914-1914: Interneringstiden.

66. Hanssen 1924, s. 27.

67. Hanssen 1924, s. 35.

68. Hanssen 1924, s. 35-36.

69. Hanssen 1924, s. 36-37.

70. Ibid.

71. Ibid.

72. Hanssen 1924, s. 38.

73. Hanssen 1924, s. 38-39, hvor Fr. Naumanns brev af 15/8-1914 er affotograferet.

74. Hanssen 1924, s. 38-40.

75. Hanssen 1924, s. 40-43.

76. Ibid.

77. Ibid.

78. Hanssen 1924, s. 44-45.

79. LSH: Bestandes Abt. 301, 1708.

80. Ibid.

81. Ibid.

82. Hanssen 1924, s. 44-45.

83. Hanssen 1924 , s. $45-46$.

84. LAÅ: RA0272/139: Hans Peter Hanssen, Rigsdagsmand.

85. Hanssen 1924, s. 51-53.

86. Hanssen 1924, s. 60-61.

87. Berthelsen udg. 1939, s. 46-48.

88. Berthelsen udg. 1939 , s. $15-17$.

89. Berthelsen udg. 1939, s. 53-54.

90. Berthelsen udg. 1939, s. 15.
91. Berthelsen udg. 1939, s. 16-17.

92. Alnor 1927 , s. 674-675.

93. Hanssen 1924, s. 65.

94. Berthelsen udg. 1939 , s. 38-41.

95. Berthelsen udg. 1939, s. 22-23.

96. LAÅ; RA0272: Hans Peter Hanssen, Rigsdagsmand: 272/-112: 19141920: Optegnelser i afsk. og aktstykker vedr. jun-jul 1914 og 19181920.

97. Ibid.

98. LAÅ: RA0272/116a: Hans Peter Hanssen, Rigsdagsmand: 19141920: Optegnelser i afsk. og aktstykker vedr. jun-jul 1914 og 19181920.

99. Schack 1970, s. 76.

100. Sarup 1934, s. 23.

101. Sarup 1934, s. 24-25.

102. Sarup 1934, s. 9-123 og s. 151-166.

103. Sarup 1934, s. 163.

104. Sarup 1934, s. 41.

105. Sarup 1934, s. 48-49.

106. Sarup 1934, s. 9-123 og s. 151-166.

107. Sarup 1934, s. 53.

108. Sarup 1934, s. 64-69.

109. LAA: RA0272/116a: Hans Peter Hanssen, Rigsdagsmand: 272/116a: Optegnelser i afsk. og aktstykker vedr. jun-jul 1914 og 19181920.

110. Hanssen 1924, s. 58-61.

111. Davidsen 1973, s. 8-15; Berthelsen udg. 1939, s. 35-37, og Pedersen 1952, s. 109-120.

112. Davidsen 1973 , s. 8-9.

113. Ibid.

114. Ibid.

115. Petersen 1952, s. 110-111, samt Berthelsen udg. 1939, s. 35-37.

116. Petersen 1952, s. 111.

117. Berthelsen udg. 1939, s. 35.

118. Davidsen 1973, s. 10.

119. Petersen 1952, s. 113.

120. Filskov 1993, s. 110-111.

121. Filskov 1993, s. 112.

122. Petersen 1952, s. 114-116;

123. Jørgensen 1946, s. 79-80.

124. T. Filskov u.å., s. 25.

125. LAÅ; RA0272: Hans Peter Hanssen, Rigsdagsmand: 272/-112: 1914-1920: Optegnelser i afsk. og aktstykker vedr. jun-jul 1914 og 1918-1920.

126. Jørgensen 1946, s. 79-80. 
127. Davidsen 1973 , s. 34.

128. Schack 1970, s. 52-96; L. Filskov 1993; T. Filskov u.å., s. 17-52; Jørgensen 1946 fsv. angår slagter Sørensens beretning.

129. T. Filskov u.å., s. 24.

130. Schack 1970, s. 58-63.

131. Ibid.

132. LSH: Bestandes Abt. 301, 1714.

133. Schack 1970, s. 69.

134. Schack 1970, s. 67.

135. T. Filskov u.å., s. 49.
136. Schack 1970, s. 87. Se også LSH: Bestandes Abt. 301, 1715 vedrørende sagen mod Andreas Grau.

137. Schack 1970, s. 85-90.

138. Ibid samt LAA: RA0664: Otto Didrik Schack: Acc. 1689-12: 19141914: Interneringstiden.

139. LSH: Bestandes Abt. 301, 1714.

140. Blandt andet i Schack 1970, s. 75; L. Filskov 1993, s. 123; T. Filskov u.å., s. 45 m.fl.

141. T. Filskov u.å., s. 45.

\section{Zusammenfassung}

Bei Ausbruch des Ersten Weltkrieges wurden ungefähr 300 dänisch gesinnte Schleswiger interniert und die dänisch gesinnten Zeitungen in Nordschleswig und Flensburg wurden verboten. Die meisten der 300 Personen waren bis Mitte September 1914 inhaftiert und wurden dann wieder freigegeben. Die Verhaftungen wurden damit begründet, dass die deutschen Behörden Spionagetätigkeit von Seiten der dänisch gesinnten Südschleswiger befürchteten. Deshalb waren schon in Friedenszeiten Listen über die Leute erstellt, die bei Kriegsausbruch verhaftet werden sollten.

Wenige Tage vor Kriegsausbruch kam der Gegenbefehl von Seiten des Kriegsministeriums und des Innenministeriums in Berlin. Die Regierung wünschte keine vorbeugenden Internierungen oder Zeitungsschließungen. Diese Verhaltensmaßnahmen wurden von den Behörden in Schleswig-Holstein nicht eingehalten. Das Generalkommando in Altona, das die militärische Gewalt in der Provinz ausmachte, führte in Zusammenarbeit mit den Landräten in Nordschleswig und dem Präsidium in Schleswig die vielen Inhaftierungen von Anfang August 1914 durch. Im Laufe der folgenden Monate entwickelte sich ein Streit zwischen auf der einen Seite den zivilen und militärischen Behörden und auf der anderen Seite den zentralen Behörden in Berlin und den Behörden in Schleswig-Holstein. Ein Streit, der erst nach wochenlangem Ringen vom Innenminister und der Regierung dem Generalkommando in Altona und den örtlichen Landräten in Nordschleswig gegenüber gewonnen wurde. Die dänisch gesinnten waren währenddessen interniert und warteten auf ihre Freiheit. 